PAPER • Full original article online Free DOI: 10.36371/port.2019.02.1.2

\title{
The defeatist behaviors of addicts in adolescence from the point of view of teachers: the causes and Counseling processors
}

Hassan A.S. Al-Qraghuli

Directorate of Baghdad Education Karkh III, Ministry of Education, Baghdad, Iraq

\section{السلوكيات الانهزامية للمدمنين في مرحلة المراهقة والشباب \\ من وجهة نظر المدرسين: الأسباب والمعالجات الارثشادية فرية

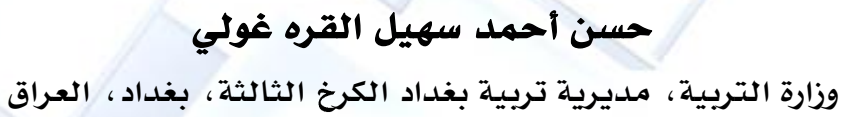 \\ Hassan.alqurquli@gmail.com}

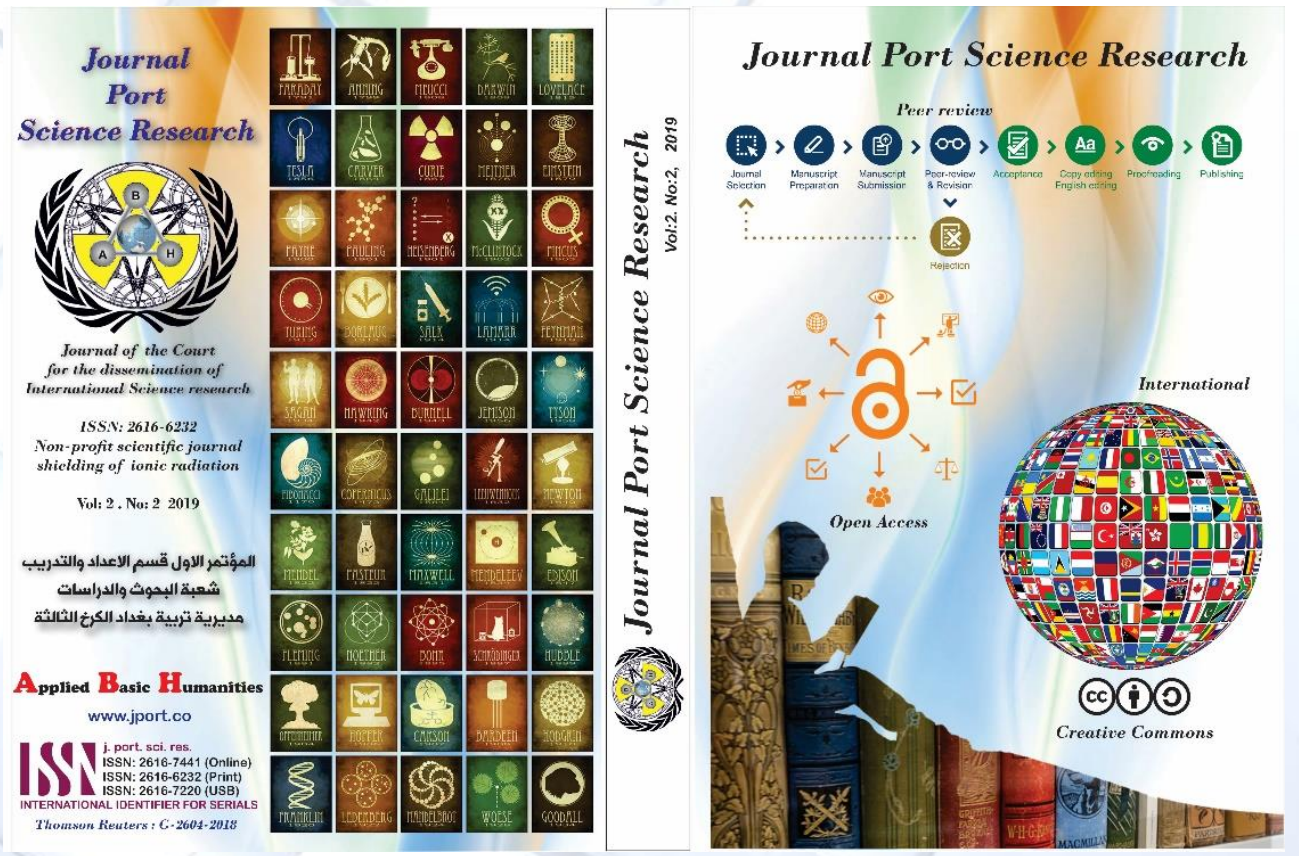

View for up https://jport.co

To cite this article: Published 2019 • (C) 2019 Bryant University United States of America Publishing Ltd. 


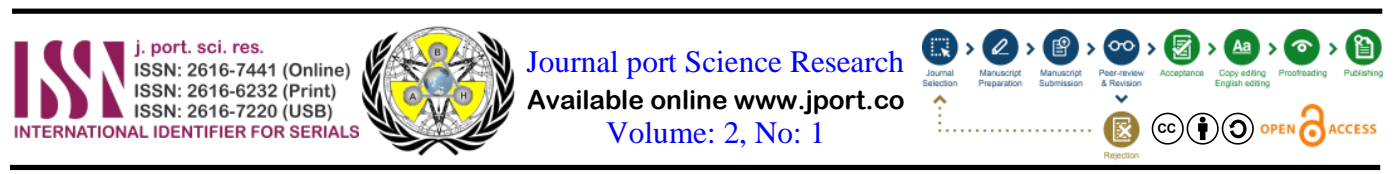

Ministry of Education Iraqi Directorate of Education Baghdad Karkh III

First Conference Department of Preparation and Training Division of Research and Studies

وزارة التريية العراقية ملديرية تريية بغداد الكرخ الثالثة المؤتمر الاول قسم الاعلداد والتدريب ثعبة البحوث وألدراسات

\title{
The defeatist behaviors of addicts in adolescence from the point of view of teachers: the causes and Counseling processors
}

\author{
Hassan A.S. Al-Qraghuli \\ Directorate of Baghdad Education Karkh III, Ministry of Education, Baghdad, Iraq \\ Hassan_201727@yahoo.com
}

\begin{abstract}
The study aimed to identify the defeatist behaviors of addicts in adolescence and youth in the teachers' perspective: their causes and their Counseling processors. The descriptive approach was used by the researcher and a random sample of teachers (270) was selected in the intermediate school. the researchers adapted the questionnaire as a tool to identify the reasons of addict's behaviors and extension treatment. The results of the research indicated the varied causes of the defeatist behavior of the addicts :The questionnaire included (41) reasons for the defeatist behavior, and the analysis of the extension treatments included (36) Counseling procedures descending order, and in the light of the results of the research, some conclusions, recommendations and suggestions crystallized .
\end{abstract}

Keywords: Act of defeatism; Addicted students; Treatment methods; Counseling.

\section{السلوكيات الاثهزامية للمدمنين في مرحلة المراهقة والشباب من وجهة نظر المدرسين: الأسباب والمعالجات فئ الارثادية

\author{
حسن أحمد سهيل القره غولي

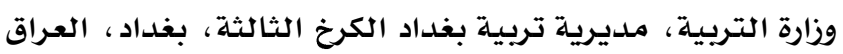 \\ Hassan.alqurquli@gmail.com
}

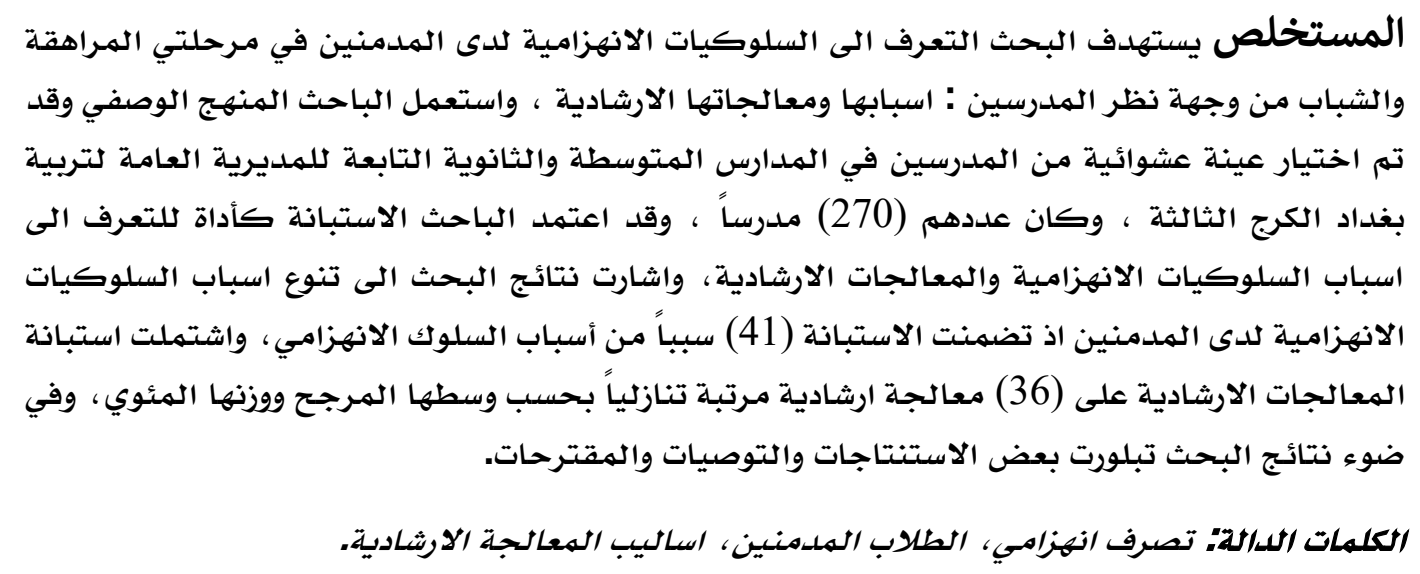

Al-Qraghuli, H. (2019). The defeatist behaviors of addicts in adolescence from the point of view of teachers: the causes and Counseling processors. Journal Port Science Research, 2(1), 11-41. 
ان انتشار الظواهر السلوكية المتعددة والمتنوعة في المجتهـع ذلك قد يعود لعوامل متعددة واسبـاب كثيرة تفرضها طبيعة الحياة التي يعيشها كل مجتمع بحسب ظروفه من حيث رفاهية ابنائه وسعادتهم او نتيجة لتعرضهم للضغوط والحرمان والخوف والقلق والاكتئاب بصفة عامـة وما يتعرض له المـراهقين والشباب بصفة خاصة، ومن هذه الظواهر الشائعة التي تشكل خطراً كبيراً على حياتهم ظاهرة الادمان وما تفرزه من سلوكيات انسحابيه وانهزامية تشكل عندهم عادات وسمات سلبية تتمثثل بالعزلكة والانطوائية والابتعاد عن الواقع بطريقة هروبيه، وهذه تعد تأشيرات سلبية تصدر عنهم في مرحلة المـراهقة والشباب مما يتطلب من المهتمين في مجال التربية والتعليه والارثـاد النفسي والتوجيه التربوي من معرفة مظاهر سلوكياتهم ومعرفة خصائصهم الشخصية. ان السلوك الانساني لا يفرض على الشخص فرضـاً لأن الفرد يختار هذا السلوك بنفسه وهو المسؤول عن أفعاله حتى تعاطي الهخدرات والادمان يمكن للفرد ان يتخلى عنه كما أقدم عليه، وان ظاهرة تعاطي المـخدرات والعقاقير الخطرة من الافعال والسلوكيات المدمرة، وهذه الظاهرة انتشرت في الآونة الاخيرة في كل المجتمعات بشكل كبير وهي تمثل خطراً رئيسياً على الصحية الجسمية والعقلية والنفسية والاجتهاعية ونوع الحياة التي يحياها الانسان [1] لأن ذلك يدل على مدى أهمية هذه المشكلة وخطورتها لدى الشباب والمـراهقين اذ لابد من الاهتمام بهذه الفئات المهمة في المجتمع بحيث تكون الأولوية لهم في عمليات التخطيط واعداد البرامـج والاستراتيجيات الاجتماعية والتعليمية والبرامـج الوقائية في الإرشاد النفسي والتوجيه والتربوي والمدرسي والاجتماعي فضلا عن الإرشاد الأسري والمجتمعي. إن "المخدرات لها أضرار كثيرة واضحة اذ توجد ترابطات بين الأنواع المختلفة مـن المخدرات وغيرها من المواد التي تؤدي إلى السلوك الإدماني"، وان رغبـة الهـراهقين والشباب في تجريب كل ما هو جديد وحب الاستطلاع والمغامرة وتقليد الصحبة السيئة ومسايرتهم في تصرفاتهم وسلوكياتهم وافكارهم والبحث عن النشوة والمتعلة وجلب السعادة وسوء استخدام ملئ الفراغ عن طريق التدخين والأكيلة يعد الخطوة الاولى لتناول العقاقير والكحول والمواد المـخدرة التي تمثل آفة خطرة ونوع من الغزو الفكري لعقولهم نتيجة الاندفاع والاستقلال والتحدي والتغلب على الهزائم النفسية ومواجهة المواقف الاجتماعية والمدرسية الضاغطة ، لذا فان ظاهرة ادمان المراهقين والشباب في المدارس الثانوية والمؤسسات التعليمية تعد ظاهرة أخطر من الغزو الثقافي ذلك لان الثقافي انما يستهدف العقول للنيل منها والسيطرة عليها بينها الادمان وترويج المخدرات بين الشباب انما يهدف الى القضاء على عقول الشباب وابدانهم" وسلوكياتهمَ في آن واحد [2] ، ويزداد خطر الادمان وما يصدر عنه من سلوكيات تجنبيه وانهزامية كل يوم مـع انخفاض سن الادمان ودخول عينات جديدة من الصبية والمـراهقين والشباب صغيري السن من طلاب المدارس والتلامدة في دائرة الموت والهلاك [3]، ويمكن للمدرسة أن تؤدي دورها في تعديل السلوكيات الانهزامية التي تصدر عن المدمنين الهراهقين والشباب ووضع معالجات وطرائق الوقاية لظاهرة تعاطي المـخدرات واداء وظائفها بشكل إيجابي وتوعية الطلاب المـراهقين بخطورة هذه الظاهرة وانعكاسـاتها المختلفة على الحالة الصحية والاجتهاعية والنفسية والاقتصادية [4] ، بالتعاون مـع المـرشدين 
والمدرسين والادارة المدرسية واولياء امور المـراهقين بصفة خاصلة وتوعية أفراد المجتمـع بصفة عامـة بأضرار المخدرات وكيفية مواجهة هذه الظاهرة الخطيرة التي تنتشر في المجتمـع بصورة مخيفة. ومـن أبرز بوابات السلولك الإدماني هو عندها يتولد لدى المـراهقين الاستعداد لتعاطي المواد لمخخدره التي تجعله يزيل الحواجز الاخلاقية والتربوية وبروز سلوكيات انسحابيه وانهزامية من الواقع الذي يعيشون فيه بحيث يصبـح الهـراهق أو الشاب قابلاً لأي اغراء أو عرض يقدم له، والحلقة الاخرى تتضمن الكحول بكل أنواعه المخمـرة والمقطرة، لذا تدل "الدراسـات والأبحاث العلمية يبدأ معظم متعاطي الحشيث أو الماريجوانا أولا بشرب الكحول" ، وبينت الكثير من الدراسات العلمية على سبيل الهثال ان استخدام المخلدرات يبدأ بتعاطي التدخين والكحول التي تعد بوابة رئيسـة في مسلسل تعاطي المخدرات وقد اشار (Hoffman et al., 1985) [5] أن تناول الكحول يمكن أن يستمر من دون "التدخين، لكن التدخين إلى حد مـا دائماً يكون متبوعاً بشرب الخمـر القوي، والاستخدام المزدوخ للسجائر والكحول القوي مرتبط بالدخول إلى عالم المخدرات الممنوعة" ، فضلا عن حلقة تأثير رفقاء السوء الذين يساهمون في فترة المـراهقة على اغراء الزملاء وسحبهم الى الانزلاق في هاويـة الادمان وما يتبعه من سلوكيات انهزامية في مواقف اجتماعية مختلفة وان العديد من العوامل التي تكمن وراء الأعراض السلبية بما في ذلك الخوف من المواقف الاجتماعية المهجدة- والانسحاب والانهزام- وتجنبها وكذلك فقدان الأمل وعدم احترام الذات هو الاعتقاد الخاطئ- بان التحسن غير ممكن بسبب تشخيص اضطراب عقلي [6] (Andreasen,et.al,1982) على سبيل الهثال (الأداء المدرسي الضعيف والهشاكل الاجتهاعية) في أثناء نهوهم خلال مرحلة المراهقة والبلوغ المبكر بسبب تزايد تعقيد متطلبات الحياة، فان هذه المشاكل الأولية في الأداء الاجتهاعي والمهني لها تأثير في تشكيل المعتقدات الخاطئة التي تؤدي إلى اختيار السلوكيات غير Couture, et.al(المؤاتية مثل العزلة الاجتماعية وتقلص المشاركة في السلوك الموجه نحو الهدف 2011) [7] وأكثر الدراسات التي يتهم دراستها حتى الآن هي معتقدات الأداء الانهزامي [8] . لهذا فالسلوك الإنسـاني "ليس فعلاً أو أفعالاً مفتتة، لكنه منظومـة متكاملة من السلوكيات والظروف الفردية والاجتماعية والبيئية، وسواء كان العمل إصلاحياً أو علاجياً أو وقائياً فينبغي له تفهم تعقيد السلوك الإنسـاني، وان تعاطي المـخدرات هو سلوك، وخيار فردي موجه ومتأثر بعوامل شخصيه واجتماعية وتريوية وتعليمية وأسرية ، لذلك ينبغي النظر إلى التعاطي بهذا المنظار السلوكي والبيئي الشامل

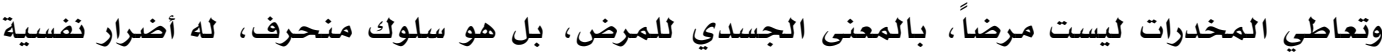
واجتماعية وطبية" [9] ، والإدمان السلوكي هو شكل من أثكال الإدمان ينطوي على إكراه على الانخراط في سلوك مـزي غير متعلق بالمخدرات- يطلق عليه أحيانا مكافأة طبيعية [10]، وان السلوك الإدماني، يشار إليه أحيانا بانه اضطرابات السيطرة على الانفعالات ويتم التعرف اليه بشكل متزايد كأشكال للإدمان التي يمكن علاجها ، ويشهل أنواع متعددة من السلوكيات الهفرطة التي تم تحديدها بأنها تسبب الإدمان ، والقهار وغيره، ومن أهم المشكلات التي يواجهها الشاب في هذه الفترة هي تلك التي تتعلق بمحاولة الشباب التحرر من السلطة الأبوية والاستقلال عن الأسرة كما تظهر ميول لدى البعض نحو التدخين وتعاطي المـخدرات والمسكّرات، وقد يميل الكثير من الشباب إلى التعامل مـع مشكلات المـجتهـع، وهذه الخصائص ليست ثابتة بل هي مظاهر سائدة مشتركة يختلف الشباب بها تبعاً ل11]. 
j. port. sci. res.

ويقع الشباب في سن المراهقة تحت طائلة التعاطي والادمان على المخدرات والكحول من باب الفضول والتجرية أو أصدقاء السوء، مع انتشار أنواع مختلفة من المخدرات التي تفتك بمستقبل المراهقين والشباب، لذلك فقد نرى هذه المشكلة بدأت تتفاقم بشكل سريع في مجتمعنا، وان تعاطي المخدرات والمواد المخدرة يقع في الغالبية العظمى من الحالات في سن الشباب المبكرة وهي فترة العمر التي يمكن فئن

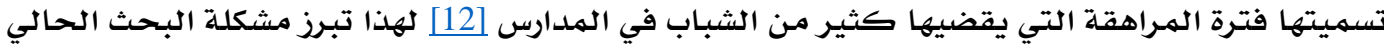

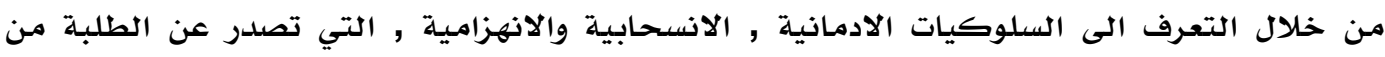

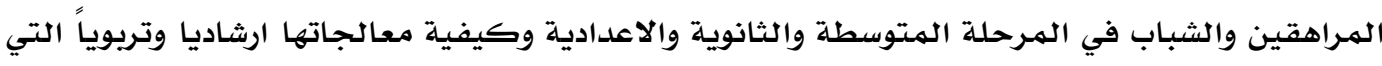
تتخذ سلسلة من الاستراتيجيات والفنيات والخطوات والفعاليات والعمليات المنظمة والمخططة كما

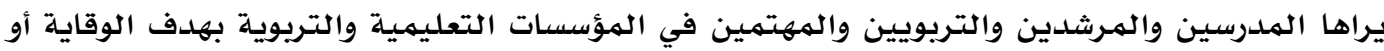

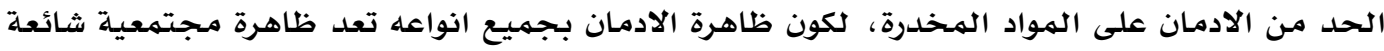

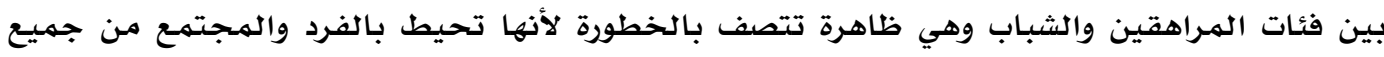
جوانبه على حد سواء، وقد أجريت العديد من الدراسات والبحوث حول ظاهرة الادمان بكل انواعه ، فقدات

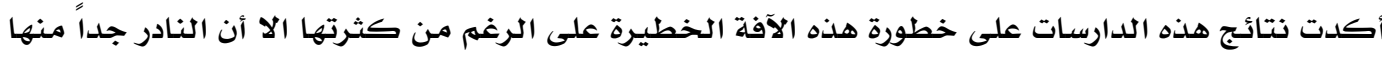

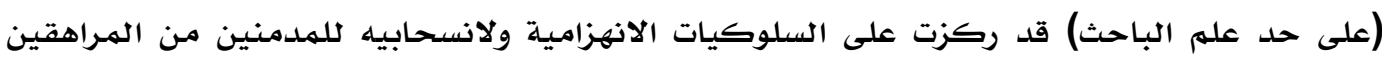

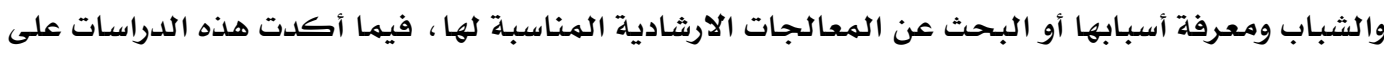

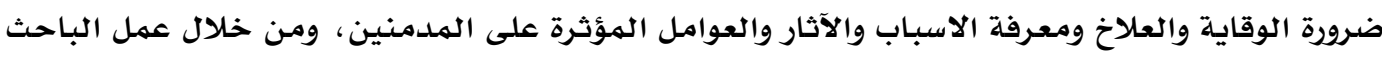

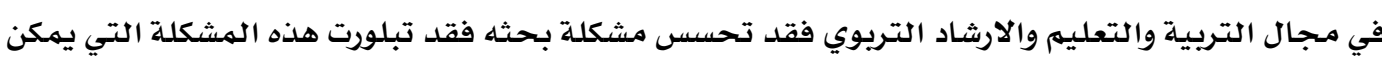

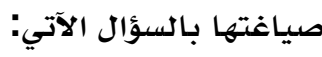
ما هي أسباب السلوكيات الانهزامية لدى المدمنين في مرحلتي المراهقة والشباب من وجهة نظر

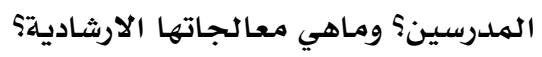

\section{• أهمية البحث}

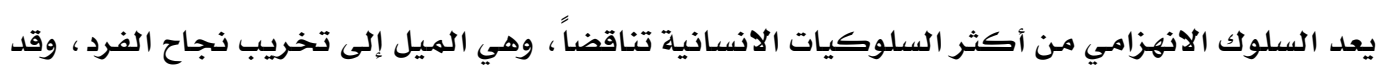
خضعت لتدقيق جديد مكثف، اذ يرى علماء النفس عادات الهزيمة الذاتية كدليل على وجود مشكلة الهات الهيل عاطفية حادة، وقد تركزت الأبحاث الحديثة على العائد النفسي الذي يتلقاه بعض الأشخاص عندما الندا

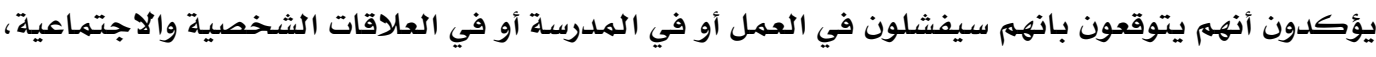

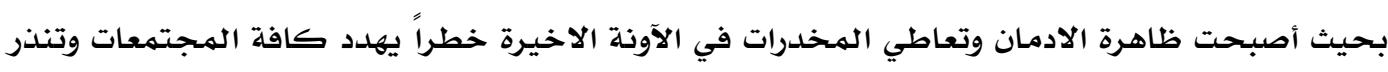

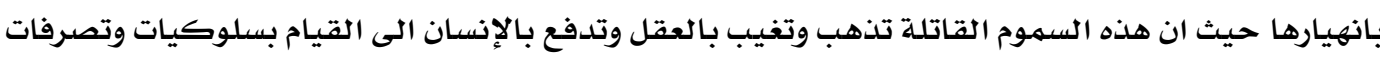

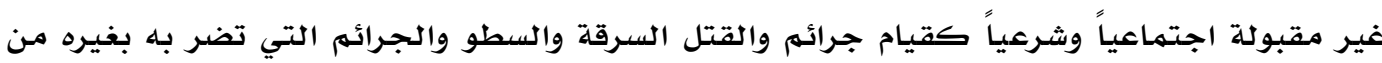
المحيطين به، وبزيادة اقبال الشباب على تعاطي هذه المواد المخدرة له يعد الامر مقتصراً على حالات

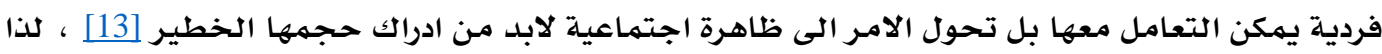

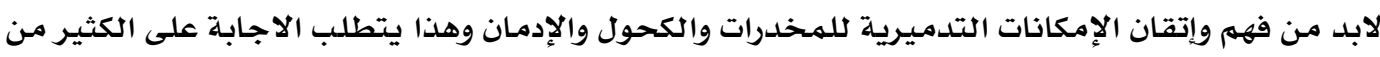

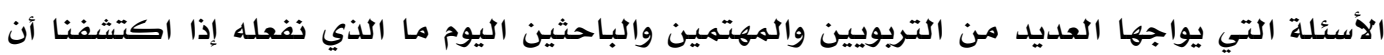
أطفالنا وشبابنا يدخنون الماريجوانا ؟ وهل هناك طريقة أكثر منطقية أو مباشرة لتقليل الضرر الذي لاني

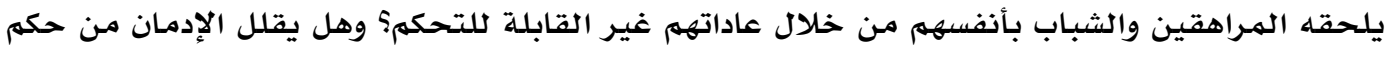

القره غولي، حسن احمد سهيل. (2019). السلوكيات الانهزامية للمدمنين في مرحلة المراهقة والشباب من وجهة نظر

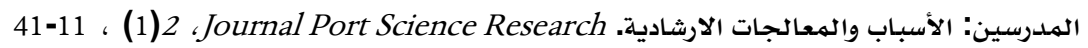


الافراد بحيث لا يمكن مساءلتهم عن سلوكهم أو عن الجرائم أو التجاوزات التي يرتكبونها بينما هم

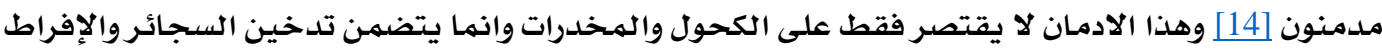
بها والمقامرة ، لذا لابد من ايجاد برامج بديلة للتفكير في التعامل مع سلوكيات الإدمان والتعاطي الذي يقع غالباً في سن المراهقة المبكرة وهي الفترة التي يقضيها الشباب في المدارس وتمتد عبر المراحل العمرية المتعددة وتبدو أكثر خطورة وشيوعاً لدى قطاعات الشباب والمراهقين، كما يرتبط التعاطي

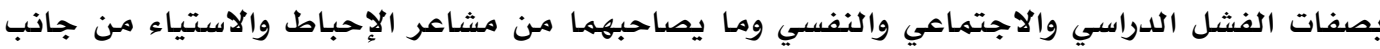
الأسرة مما يؤدي إلى نفور الطالب من الموقف التعليمي والتربوي [15]ـ. ويرى الباحث من خلال ملاحظاتهم لبعض الطلاب المراهقين في المرحلة المتوسطة عن طريق المقابلات الفردية ثمة علامات جسدية وأخرى متعلقة بالسلوك التجنبي والانهزامي الذي ترتبط بكل نوع لهن من أنواع المسكرات منها الكحول ووضع بعض البدائل المخدرة في الاركيلة، كما توجد سلوكيات مشتركة بين الشباب والمراهقين المدمنين ترتبط بجميع أنواع المخدرات وقد تكون علامات الإدمان وقد الداند

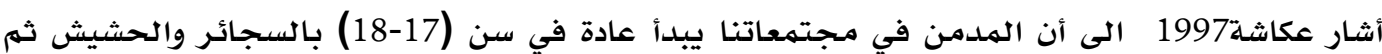
الحبوب [16]، ومن خلال التعامل مع المراهقين في مواجهة إغراءات تعاطي الكحول والمخدرات غير المشروعة ، وهناك بعض الشباب الذين يجدون مصادر اللّّة والسرور تتركز في القيام ببعض الأنشطة الكرال

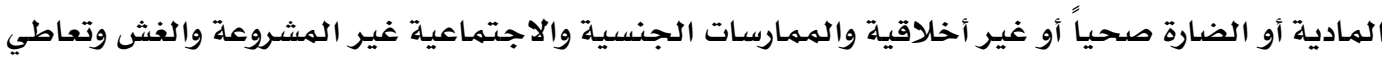

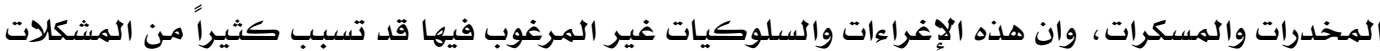

النفسية التي يواجهها الفرد [17]. وتشير الأدبيات إلى أن الانهزامية التعبير الصامت عن الاستسلام التام للمصير دون القدرة على القيام بأي فعل إرادي لتغيير وجهة الحياة الشخصية، وتوقع الفرد للهزيمة وترقبه لها وتسليمه بحميتها ، ومن

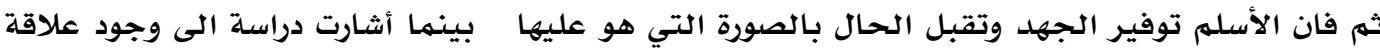
ارتباطية عالية بين الافكار اللاعقلانية والسلوك الانهزامي (محمد، 2016) [18] فالإدمان على التدخين والأركيلة والكحول والحشيشة يعد شكل من أشكال السلوك الانهزامي الذيى يعجز الفرد عن ايقافه على الرغم من نتائجه المعاكسة، اذ يحصل بعض الشباب على المتعة والبهجة المؤقتة ومن ثم الهروب والانسحاب من المواقف والظروف والمشكلات التي تواجهه بدلا من أن يفكر بحلها فانه يهرب الى تناول المخدر وبذلك يسجل انهزامه بشكل غير مباشر وهذا ينطبق بدقة بالغة على كل سلوك انسحابي وانهزامي، وان المشكلات السلوكية التي يواجها المراهقين والشباب في هذه المراحل تتضمن الاعتياد والادمان وسوء استخدام العقاقير وضعف الدافعية والافراط في التدخين والتبخ والكحول والمواد

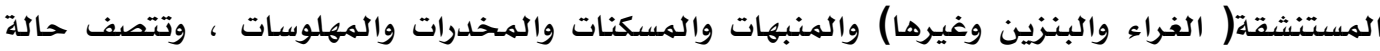

- وجود رغبة قهرية قوية في الاستمرار في أخذ العقار والحصول عليه بأية طريقة.

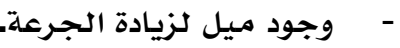

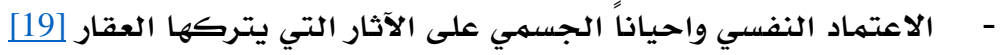
فيما أشارت نتائج دراسة [20] الى أن الفئة الاكثر تعرضاً لتعاطي المخدرات هي فئسة المراهقين وهناك

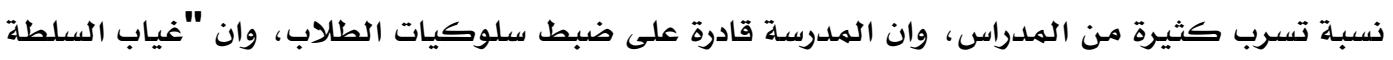
Al-Qraghuli, H. (2019). The defeatist behaviors of addicts in adolescence from the point of view of teachers: the causes and Counseling processors. Journal Port Science Research, 2(1), 11-41. 
يساهم في انتشار الجرائم والسلوكيات الخاطئة وتعاطي المخدرات [21] وإن تعاطي المخدرات والإدمان

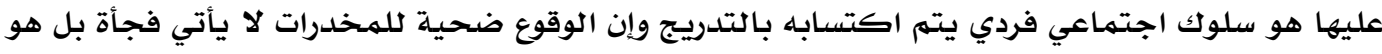
عملية مستمرة تبدأ من انحراف أو خطأ بسيط بتقبل تجريب المخدرات بدافع حب الاستطلاع أو بضغط من رفاق السوء، لكن دورة التعاطي هذه تستمر، وتأخذ ضريبتها من سلوك المتعاطي المراهق وعلاقاته الاجتماعية ووضعه الصحي، لذا تعد المراهقة جسر عبور بين الطفولة والرشد، كما أنها الطريق الذي لفي

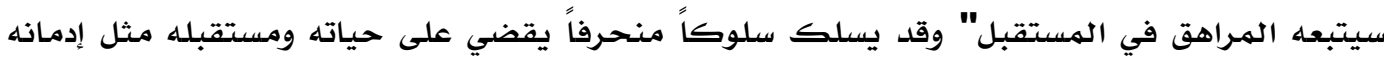
وتعاطيه العقاقير المخدرة ، وان الظاهرة الحديثة والمؤسفة هي انتشار الإدمان على جميع المواد بين الشباب والمراهقين [22] وان ما يصدر عنها من تغيرات وسلوكيات وتناول كل ما هو محظور من الاركيلة والتدخين وتناول الكحول والشعور بالنشوة والمتعة والاستقلال ومن ثم ادمان هذه السلوكيات وان كانت مخالفة للمعايير الاجتماعية والاخلاقية، ويمكن خلاصة أهمية البحث من الناحية النظرية في النقاط

1) يعد هذا البحث أثراء للمعرفة النظرية لمجموعة بحوث حول السلوكيات الانهزامية والانسحابية لدى المدمنين من المراهقين والشباب في المدارس الثانوية، فضلا عن أن البحث يكتسب أهميته كونه يتناول السلوكيات الانهزامية للمراهقين المدمنين من حيث الأسباب ووضع المعالجات الإرشادية من وجهة نظر مدرسيهم التي يمكن أن تحصنهم من الادمان.

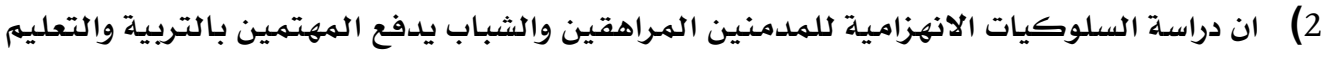
والارشاد التربوي في المدارس الى ضرورة التعامل معها والبحث عن المعالجات الارشادية للتصدي التهاي لهذه الظاهرة وما يصدر عنها من سلوكيات وافعال وتصرفات والتي يمارسها الطلاب في البيئة الدراسية والمجتمعية، والتخطيط لوضع معالجات وقائية وبرامج ارشادية جمعية وفردية لتحصين المراهقين والشباب من الوقوع فريسة الادمان بكل أشكالهه. وأما أهمية البحث من الناحية التطبيقية فتكمن في الآتي:

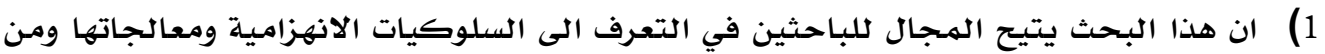
ثم اجراء برامج وقائية وإرشادية لها فاعليتها في وضع معالجات لسلوكيات المدمنين الانهزامية، وكذلك الافادة من الاستبانتين.

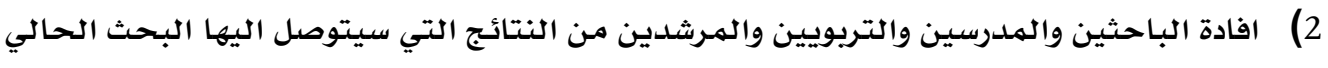
في تشخيص السلوكيات الانهزامية للمراهقين المدمنين، فضلا عن مساعدة المرشدين واولياء امور الطلاب في معرفة ما يصدر عن ابنائهم وطلابهم من سلوكيات وافعال ومن معرفة متطلبات وحاجات المراهقين المدمنين في هذه المرحلة الخطرة من حياتهم العمرية والدراسية.

وجهة نظر المدرسين. 2) التعرف الى المعالجات الارشادية للسلوكيات الانهزامية لدى المدمنين في مرحلتي المراهقة والثباب من وجهة نظر المدرسين. 
• • حتصر حدود البحث الحالي على (المدرسين في المدارس المتوسطة والثانوية والاعدادية التابعة لقسم التاجي والطارمية)، ضمن المديرية العامة لتربية بغداد الكرج/ الثالثة، للعام الدراسي (2018-2019) للدراسـة الصباحية.

\section{مصطلحات البحث \\ وردت في البحث المصطلحات الآتية:}

أولا: السلوكيات الانهزامية (Defective behaviors) وقد الهصدات الاتية عرفه كل من:

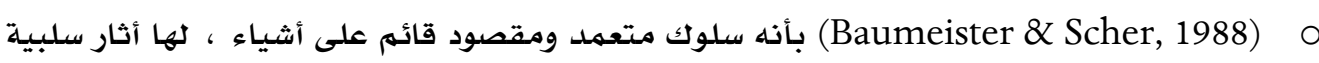

على النفس أو الحالة النفسية بشكل واضح تسبب الفشل وتجلب المتاعب. [23]

(Mervis, 2016) فقدان الأفراد الإحساس بحقيقة قدراتهم وخبراتهم وقوة تأثيرهم على الأحداث

الجاريـة والاستسلام لها والشعور بالذنب والانسحاب والاستبعاد الاجتماعي وتدمير الذات والعدوان

والخوف من الفشل [24]

\section{يعرفه الباحث}

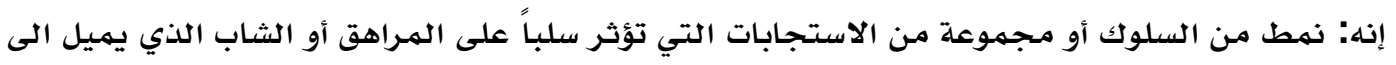
الاحجام عن التفاعل الذي يتمايز بإبعاده عن القيام بهمهات حياتية والاخفاق في المشاركة الجماعية وضعف في الاداء الذي يرافقه احباط وتوتر وخيبة أمل والهروب بدرجة كبيرة عن الواقع والانعزال وعدم لدام

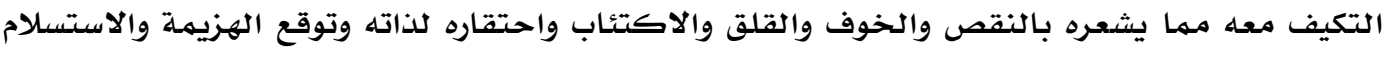

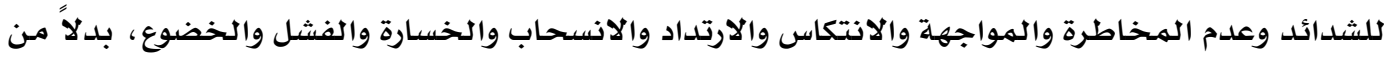
المفاهيم التي تكون بالضد منها. التعريف "الاجرائي للسلوكيات الانهزامية": الدرجة الكلية التي يحصل عليها المستجيب من (المدرسين)

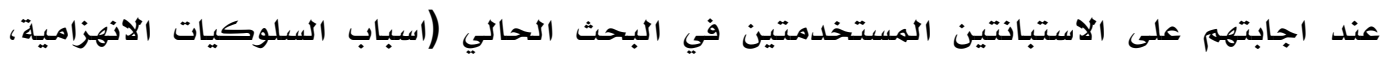
والمعالجات الارشادية). ثانياً: المدمنين: (Addicted): عرفهات الجرشادئ. O (الشريف، 2015): المراهـق المدمن هو الذي يتراوح عمره بين (19-26 سنة) ، ويتعاطى بشكل فعلي وليس تجريبي ومتكرر لمدة لا تقل عن أربع سنوات لمؤثرات عقلية متعددة ومتوفرة محليا.

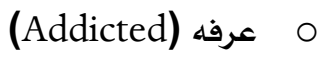
(الشريف، 2015): المـراهـق المدمن هو الذي ىتراوح عمره بىن (19-26 سنة) ، ويتعاطى بشكل

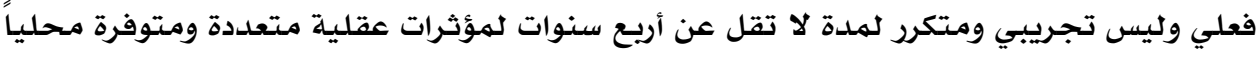

ثالثا: مرحلة المراهقة والشباب: (Adolescence and youth Stage) (رقيق وبنش، 2017): مرحلة من مراحل الحياة تتمايز بسرعة النمو والتغيير في كل مظاهرها النها النهائية

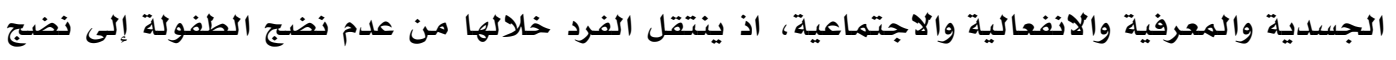
Al-Qraghuli, H. (2019). The defeatist behaviors of addicts in adolescence from the point of view of teachers: the causes and Counseling processors. Journal Port Science Research, 2(1), 11-41. 
الرثد والشباب، وهي الجسر الواصل بين هاتين المرحلتين، وهي مرحلة حساسـة للمراهق فيها تحدث له تغيرات جذرية نفسية وجسلدية تقوده إلى طريق الانحراف وانتهاخ سلوكيات غير سوية تجعله يعيث في عالم غير العالم الذي هو فيه ألا وهو الإدمان على المخدرات التي تعد اليوم ظاهرة اجتماعية مستعصية يسلكها المراهق [26].

رابعاً: المعالجات الارشادية (Counseling processors) (Waller,2017) [27]. المنحرفة التعريف النظري: يعرفه الباحث أساليب وطرائق واستراتيجيات وفنيات ارشادية تهدف الى تصحيح مسار الانحراف للسلوكيات التي تصدر عن المـراهقين والشباب لمنعهمم من الوقوع او الانزلاق في خطر وآفة السلوكيات الادمانيـة، وبذل الجهود لمساعدتهم في التغلب على الظروف والتحديات والصعوبات والازمات النفسية والاجتماعية والدراسية التي تواجههم والحد منها ووقايتها للحيلولة دون اتباعهم سلوكيات منحرفة انسحابيه وانهزامية او القيام بتصرفات وافعال تكون مخالفة لكأنظمة التريوية والتعليمية والمعايير الاخلاقية كما يراها المدرسين من خلال اجاباتهم على فقرات الاستبانة التي أعدت في البحث الحالي. التعريف الاجرائي: الدرجة الكلية التي يحصل عليها المستجيب من عينة البحث (المدرسين) عند استجابتهم على الاستبانة المستعملة (المعالجات الارشادية للسلوكيات الانهزامية لدى المدمنين).

$$
\text { الإطار النظري }
$$

اولا: السلوكيات الانهزامية:

$$
\text { O مفهوم الانهزامية والسلوك الانهزامي }
$$

الانهزامية من أكبر أسباب الفشل، وتهدم المعنويات، وموقف الانهزامي وسلوكه، والشخص الانهزامي

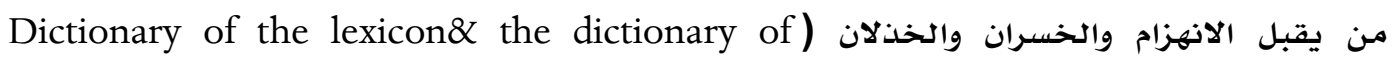
Contemporary language, 2004 ،والانهزامي هو شخص يفكر أو يتحدث بطريقة توحي بأنه يتوقع عدم نجاحه [28] ويقال انّ الهزيمـة شيء يُتعلهم، والانهزامية تعني معتقدات الفرد بضعف أدائه أو الأفكار

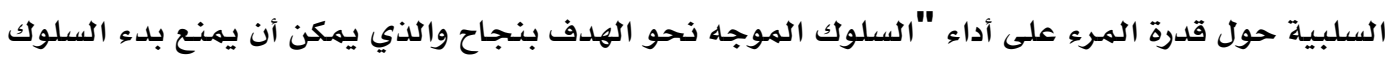
والهشاركة [29] ،ويشير السلوك الذي يهزم الذات إلى فكرة مفادها: إن الناس عن علم وعن قصد يعملون الأثياء التي من شأنها أن تسبب لهم للفشل وتجلب لهم المتاعب أو إيذاء أنفسهم، ويصف سلوك هزيمهة

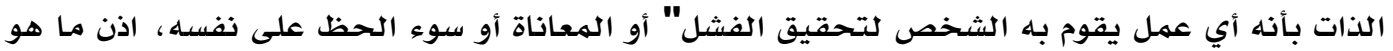
السلولك المهزوم (defeating behavior) ؟ ، يتضهن السلوك النفسي المهزوم ذاتياً في شكلين متداخلين هما الاعتقاد بان المراهق المدمن لن ينجـح، والقيام باتخاذ تلك الإجراءات بوعي أو دون وعي لضمان تلك النتيجة ولغرض تدمير الذات ، اذن لمـاذا الهـراهقون والشباب يفعلون ذلك؟ ،وهناك من يعتقد منهمم أن كل شيء ، بما في ذلك نزعاتههم المدمـرة ذاتياً هي تنبع من الطفولة ولها جذورها في خيبة الأمل وان توقع الهزيمة هي نتيجة للحياة، وان سلوك هزيمـة الذات يعمل على مضاعفة التهديد ، وان مفهوم الهزيمـة أو الانهزام هي مـرادف لمفاهيم الاستسلام للشدائد وعدم الهخاطرة والهواجهة والانتكاس والارتداد والانسحاب وعدم الصمود النفسي والخسارة والفشل والخضوع، بدلاً من المفاهيم التي تكون بالضد منها 
مثل النجاح والفوز والغلببة والشعور بالانتصار والمواجهة والتحدي والصلابة والقوة والمرونة او اكتساب القوة ضد الضغوطات المستقبلية، أو التحديات أو الأزمات أو الصدمات، وعلى سبيل المثال مفهوم التغلب او الغلبة فقد حدد ثلاثة سمات أساس لتجاوز المفهوم: [30]

\section{ماهية السلوثك الاثهزامي}

فالسلوك الانهزامي يعني حالة من الشعور بالعجز وقلة الحيلة وانعدام الفاعلية الشخصية في الحياة والتعاسـة العامـة، وهو دال في جزء منـه على الأقل للتعرف الى الأحداث الصـادمسة والظروف العصيبـة والأحداث الحياتية الضاغطة، كهما رأى (ابو حلاوة 2013) ان السلوك الانهزامسي حالة نفسية ذات مضامين معرفية ووجدانية تسيطر على الفرد، تتجسد في الشعور بالعجز وقلة الحيلة اتجاه أحداث ووقائع الحياة المختلفة في الحاضر والمستقبل، وتقترن بمشاعر الكآبة والياس والحزن، مع اقتصاد الفرد للفاعلية والحيوية والذاتية، مما يدفعه إلى الاستسلام والركون وتقبل واقعة الشخص من دون بذل أي مجهود لتغيره وتبعية تامسة للآخر [31]، والسلوك الإدماني هو سلوك يتصف بكونه مجزياً ومعززاً، ومنبـه معزز المـحفزات التي تزيد من احتمال تكرار السلوك المقترن بها ويسبب اعتماد نفسي- أي اعتماد يتضمن أعراض انسحابيه تشهل تأثيرات عاطفية- وتحفيزية مثال: الانزعاخ وانعدام التلذذ، ويجعل الشخص المدمن يفكر بطريقة معينة تجعله دائما يشعر بالنقص ويشعر بالخوف والقلق والاكتئاب ويحتقر نفسـه، يشعر أنه أقل ممن حوله مها يجعله بطريقة غير واعية ينظر أو يتعامل مع الهجتهـع حوله بنظره أو بطريقة معادية. ٪ القدرة على الاعتراف أو الاعتراف بأن السلوك أو الموقف أو الحدث أو المشكلة موجودة وغير

$$
\text { مرغوب فيها أو معيقة أو غير صحية. }
$$

خ إظهار الجاهزية والعزم على تغيير أو التغلب على السلوك أو الهوقف أو الحدث أو المشكلة. • الاعتقاد بأن الجهود المبذولة لتغيير السلوك أو الموقف أو الحدث أو المشكلة أو التغلب عليها ستحسن من جودة الحياة المستقبلية، ويعرف التغلب بأنه عملية متعمدة ومدروسـة لتغيير أو قهر ظرف إشكالي، أو التحدي أو الشدائد التي ينظر إليها ذاتياً من أجل العيث مستقبلاً أكثر

صحة وأكثر سعادة (Walker \& Mittal,2011)

\section{صفات الشخص الاثهزامي}

من هو الشخص الانهزامي؟ (Who is the defeatist person): هو الشخص الذي يتصف بسمات الشخصية الضعيفة والسلبية والمتشائمـة ويشعر بالإحباط وتوقع الفشل لذاته وهو شخصية مشلولة لديها الاستعداد المسبق للفشل اكثر من استعدادها للنجاح، وفي الوقت نفسه يكون محبط للآخرين في اداء الههمات ويبحث في دقائق الامور ويطالب الاخرين بالإنجاز العالي فوق مستوى طاقاتهم حتى يُشعرهم بالعجز والنفور ويبحث عن الاخطاء ويكون متشكك ومتردد ويشعر بالوسواس القهري ويسيء الظن

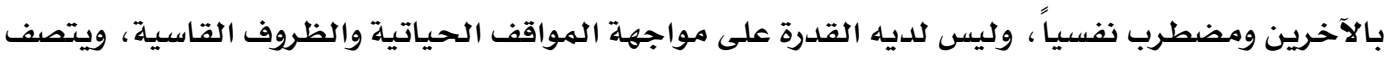
بالمعارضد والرفض، ويكون "شخص فوضوي لا يخطط لما يقوم به وليس لديه اهداف مستقبلية يسعى الى تحقيقها ومن خصائص الأشخاص الذين لديهم سلوك هزيمهة الذات، وقد ذكرها (العاسهي 2017)

• إنها لا ينتهون من المهام التي بدأوا فيها ، ويحدثون أنفسهم بأنهم قد استكملوا المهمـة. 
• يشعرون بالعجز عند قيامهم بمهامهم أو أنشطتهم، ودائماً يضعوا نصب أعينهم الفشل قبل الاستعداد للعمل، ويصبحون متحمسين على نحو مفرط حول خططهم المستقبلية، وأن هذه الخطط جاهزة للتنفيذ، لكنهم بسرعة يجدون أنفسهم يشعرون بالعجز وقلة الحيلة.

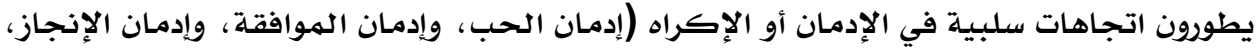

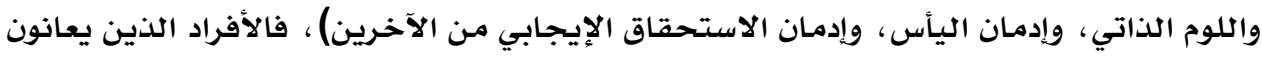

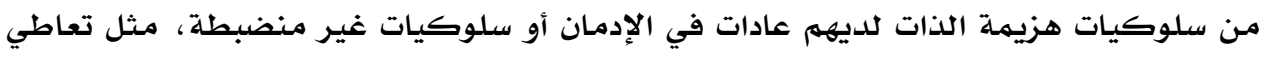
المخدرات، إدمان الجنس، الإنفاق القهري-القمار، والغضب واضطرابات، وقد يكون لديهم نظرة متشائمة للعالم". قد يكون لديهم الكثير من الضعف في العلاقات الاجتماعية مثل: لا أحد يفهمني أو مثلي وهناك الك التهات

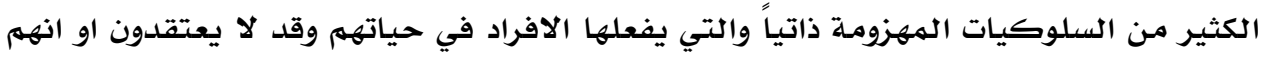

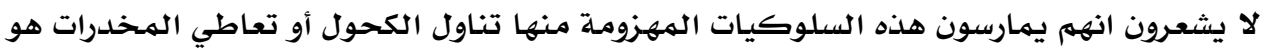

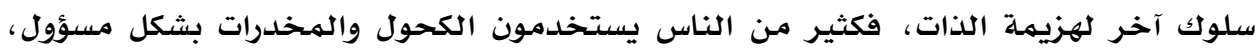
ويفعلونها للحصول على المتعة أو تخفيف الألم ولكن بالنسبة للمدمنين، وفي بعض النه الحالات لهات

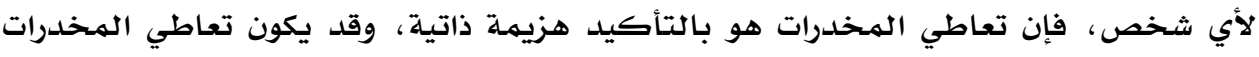

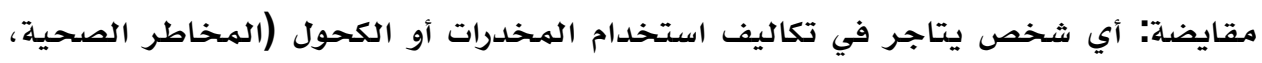

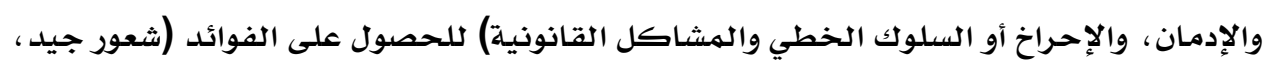

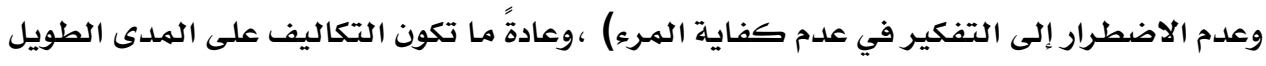

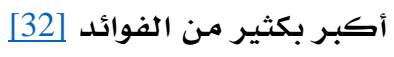

أسباب السلوكيات الانهزامية: تتضمن أسباب نفسية وأسرية واجتماعية لها أثر كبير في السلوك الانهزامي منها الآتي:

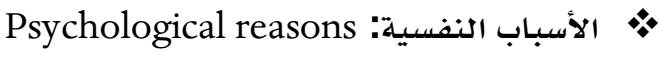

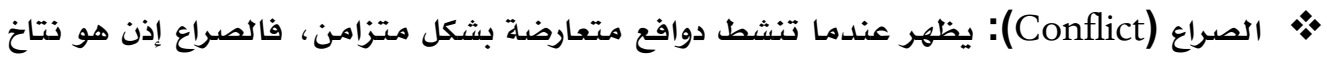

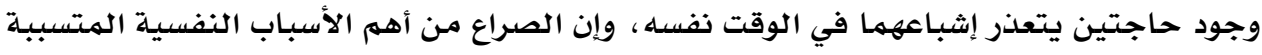
في المشكلات النفسية ويظهر الصراع من خلال مواقف عديدة منها التجنب مقابل المواجهة، والاعتمادية مقابل الاستقلالية.

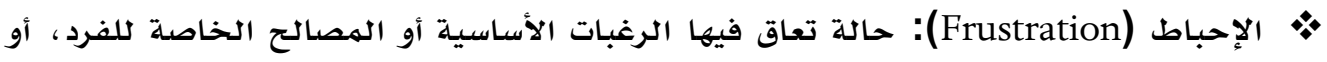

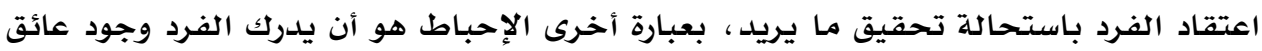
يمنعه من تحقيق أهدافه في المستقبل.

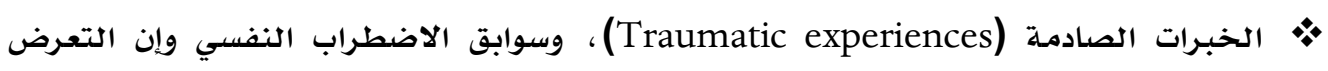

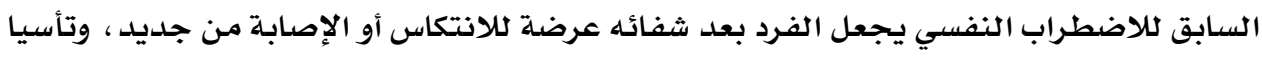

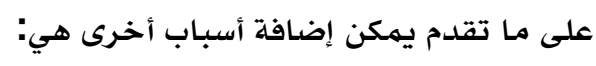

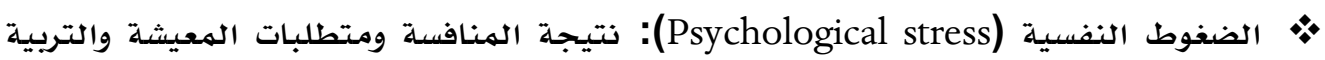

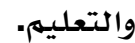


• الإطار المرجعي الخاطئ (Wrong reference frame): بشأن الحقيقة والقيم والاتجاهات

والأفكار والمعتقدات والنظرة غير الواقعية للذات وللآخرين وللأحداث [33]ـ.

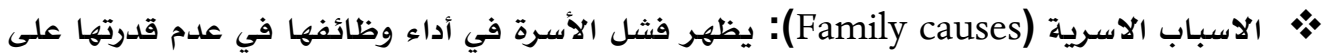
أداء المهمات المتصلة بدورة حياة الأسرة، والاساليب التربوية المتبعة فيها التي تتباين بين

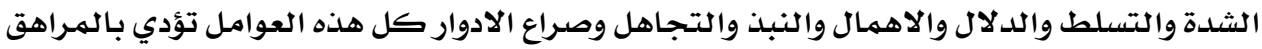
الى الخضوع والسلبية أو إلى الثورة والتمرد والانسحاب والانهزام في مواجهة الظروف الحياتية

$$
\text { المتقلبة والتغيرات المتسارعة. }
$$

* الاسباب الاجتماعية (Social causes): وهذه تتضمن العوامل البيئة والاجتماعية والوسط الاجتماعي الذي يعيش فيه الفرد، وفي حالة عدم توافق الفرد مـع الاخرين قد يشجعه على الإلى

$$
\text { العزلة والوحدة والسلوك الاجتماعي الانهزامي. }
$$

اسباب تربوية وتعليمية واقتصادية ومجتمعية وبيئية وعوامل تأثير وسائل الاعلام السلبي.

$$
\begin{aligned}
& \text { معايير تحديد السلوك الانهزامي: وهي على النحو الآتي: } \\
& \text { • يكون الفرد مستقلاً من الآخرين. } \\
& \text { • يضحي بحاجاته من أجل الآخرين. } \\
& \text { • لديه إحساس عال بالصح والخطأ. } \\
& \text { • لا يتذمر من كونه مستغلا من الآخرين. } \\
& \text { • يهتم كثيرا لرأي الآخرين في تقديم أدائه. } \\
& \text { • يشعر بمعاناة كبيرة ولا يبدو سعيداً. } \\
& \text { • لا يسمح بتقديم المساعدة إليه من الآخرين. }
\end{aligned}
$$

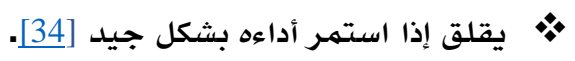

ثانياً: الادمان Addiction

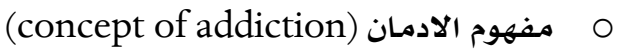

الادمان مصطلح يستخدم للدلالة على الاعتماد الجسمي على المادة المدمنة- العقار- ويتضمن الادمان تطوير حالة من الاحتمال والانسحاب، الانهزام، فعندما يتوقف الفرد فجأة عن العقار الذي تم الادمان الاندان

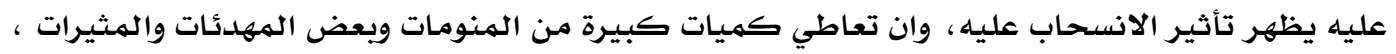

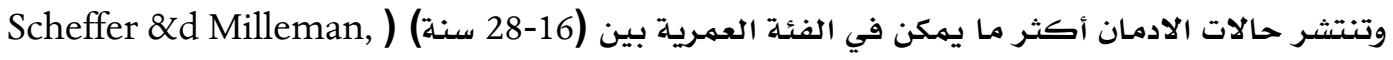
1989) ، اذ يبدأ المراهقين والشباب في مرحلة التجريب والاستمتاع بالعقاقير المدخلية وتعاطيها التي تشمل التبخ والسكائر والأركيلة والحشيشة والكحول ومواد الاستنشاق والحبوب وسوء استخدام

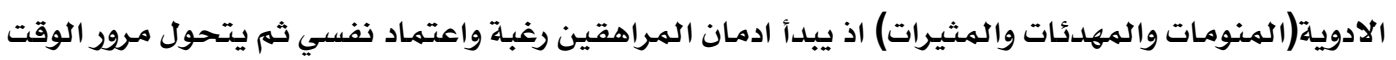

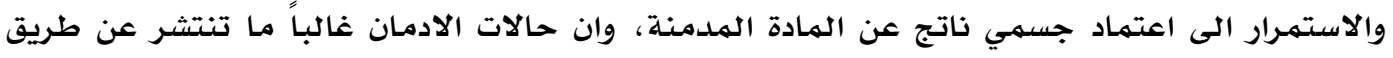

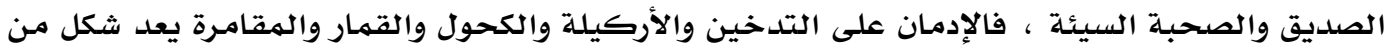
أشكال السلوك الانهزامي الذى يعجز الفرد عن ايقافه على الرغم من نتائجه المعاكسة، واستخدم

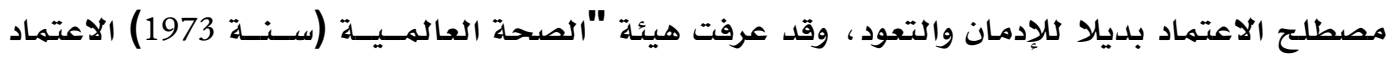

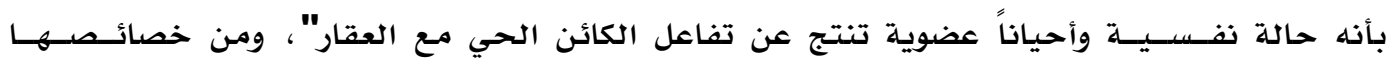
Al-Qraghuli, H. (2019). The defeatist behaviors of addicts in adolescence from the point of view of teachers: the causes and Counseling processors. Journal Port Science Research, 2(1), 11-41. 
استجابات وانماط سلوك مختلفة تشمل دائماً الرغبـة الملحة فـي تـعـاطـي العقار بصورة متصلة أو دوريـة الآثـار المزعجة التي تنتج من عدم توفرها

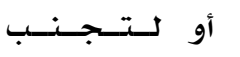

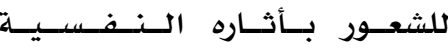

.(Demerdash, 1982)

ان أهم مـا يمايز الهـراهق المدمن هو سلوكياته الانهزامية والانسحابية ، "لذا فان الانسحاب هو الحالة التي يكون عليها المدمن إذا توقف عن تعاطي المخدر"، وهي مجموعة أعراض تنجم عن محاولة الجسمى التخلص من آثار سموم الهخلدر وتختلف السلوكيات التي تصدر الهـراهق الهدمن بحسب نوع الهـخدر، ومن أمثلـة أعراض الانسحاب في حال إدمان (المنشطات والمنبهات) ، يكون "مزاخ المـراهق مكتئب وثعوره بالتعب واضطراب في النوم وأحلام مزعجة" ، وبالنسبـة للانسحاب الكحولي تتمثل الأعراض في الارتعاشات

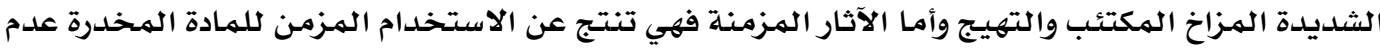
القدرة على الامتناع أو الكف عن سوء الاستعمال الذي يؤثر على الانتباه والذاكرة وانخفاض مستوى الأداء

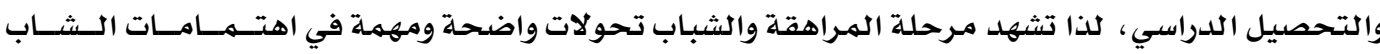
الاجتماعية وسلوكه الاجتماعي ويغلب على الشباب تقلب الحالة المزاجيةت- من الشعور الغامر بالسعـادة والراحة إلى الإحساس بالانقباض ، وذلك لأنهم فريسة سهلة لأحلام اليقظة من جهة والمخاوف والقلق والغيرة والحسد من جهة أخرى، وتـكـون حـاـــة التقلب الهزاجي هذه أقوى وأشد وضوحاً في مـراحل

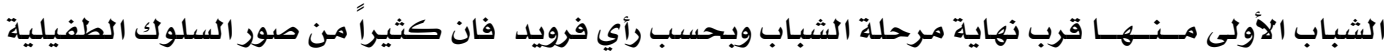
في مـرحلـة المـراهقة وبداية الشباب ريما كانت بقايا أو آثار لعمليات الكبت والقمع) التي تحدث لبعض التصرفات والرغبات في مرحلة الطفولة ومن المظاهر السلوكية للمـراهق الملدمن ما يأتي : • الانطوائية والميل الى الانعزال عن الاخرين بصورة غير عادية. • الاهمال وعدم الاهتمام بالمظهر.

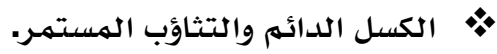
• شحوب الوجه والعرق ورعشة الاطراف.

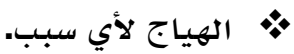
•الاهمال الواضح في الامور الذاتية وعدم الانتظام في الدراسة والعمل. • بهمال الهوايات الرياضية والثقافية. • اللجوء الى الكذب والسرقة والحيل الخادعة للحصول على المال لشراء المخدرات. O سمات المدمنين وسلوكياتهم والعوامل المؤثرة فيها.

ومن السمات التي يمتاز بها المراهق الملدن وما يصاحبها من سلوكيات وعلامات منها لضعف والخمول والشعور بالكسل والعزلة والانطواء والاكتئاب والسلوك العدواني والسلوك العنيف والذهاني وتغييرات في السلوك والاشتباك أو العراك وتحولات سريعة في الانفعالات والسلوك المتهور وفقدان السيطرة على النفس والغضب والتغييرات السلوكية المفاجئة والانسحابية والانهزامية من المواقف، والخداع والكذب والتعب والارهاق عند بذل أقل مجههود والتكاسل عن اداء الواجبات الدراسية والرغبة في النوم داخل الصف في اثناء الدروس والنعاس نتيجـة السهر والعلاقات السيئة مـع الزملاء وكثرة التغيب عن المدرسة والسرقة لتعويض حاجاته والرجوع الى البيت متأخراً وتدني الهستوى الدراسي أو تدني أدائه التحصيلي ومجالسـة الصحبة 
السيئة والميل إلى الانظواء والوحدة، والحرمان والعوز والثراء الفاحش التبذير يؤدي بالمراهقين والشباب الى التصرف بسلوكيات إدمانيه تتصف بالانسحابية والهزيمة تارة، وتارة أخرى تتصف بالمغامرة والمخاطرة تحت تأثير المادة المخدرة.

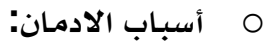

ان للإدمان أسبابه المتعددة ودوافعه المختلفة منها العوامل النفسية والعوامل الاجتماعية: والعوامل البايلوجية، وقد نلاحظ في مجتمعاتنا هو استيراث السلوك المنحرف من الآباء الى الأبناء فالأب المدمن

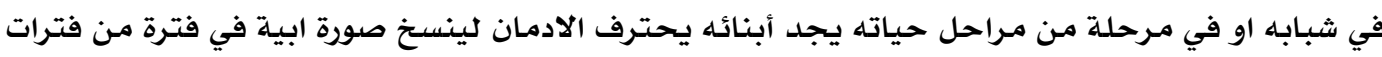
حياته [35].

\section{0 المعالجات الارشادية للسلوكيات الانهزامية للمدمنين.}

يمكن أن تتم الوقاية والمعالجة عن طريق جلسات العلاخ الفردي أو الجماعي أو العائلي والوقاية من العنائ

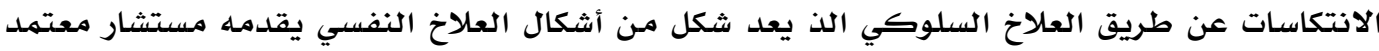
متخصص في الكحول والمخدرات واقتراح استراتيجيات لتجنب المخدرات ومنع الانتكاس والتأقلم والتدريب التيب على المواجهة ، والتواصل مع المراهقين المدمنين والاصغاء والاستماع لهم وتقديم الدعم النفسي والاجتماعي والصحي لهم وان يكون الأب والمرشد والمدرس والزميل المؤثر قدوة حسنة وانموذجاً ايجابياً لهم في المحاورة والنقاش والاقناع المنطقي لكي يتم الاقلاع عن المادة المخدرة تحت اشراف متخصصين لإقناع المدمن بأهمية الدخول في برنامج علاجي.

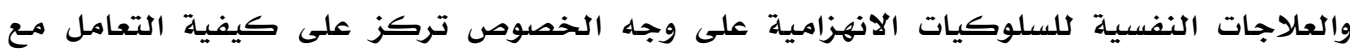
الانتكاس، وفي العادة يته تحذير الشباب من أن تعاطيهم للمخدرات هو سمة دائمة، وان معرفة كيفية وضع الحلول والمعالجات للسلوكيات الادمانية الانسحابية والانهزامية يتطلب ذلك من القائم بالعملية العلاجية والارشادية معرفة دورة الادمان التي يسير عليها المراهقين والشباب المدمنين ، اذ تبدأ عن طريق رغبة ملحة ومن ثم الانخراط في السلوك الادماني والشعور بالذنب ومن ثم احتياخ عاطفي والاعتياد والادمان والبحث عن العلاخ والتعافي ومن ثم مرحلة الانتكاس التي تشكل أخطر المراحل بالنسبة للمراهق

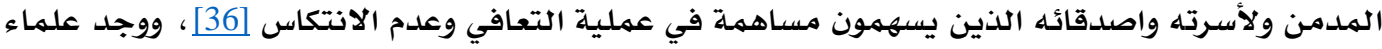

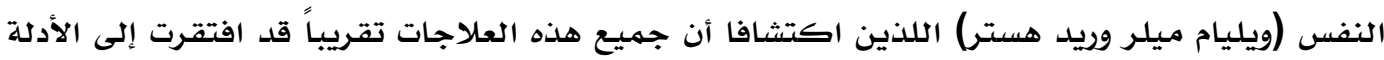

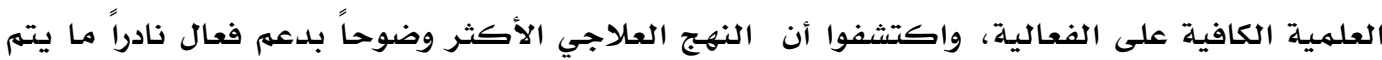
استعماله في البرام-ج العلاجية (Miller\& Hester, 1986).

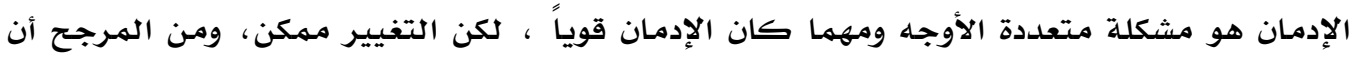
يستمر السلوك بسبب الدور الذي تؤديه المادة في خلق مشاعر النشوة وتهدئة الجسم والقضاء على الألم المهر وغيرها ، وهذا يحفز التعزيز لاستعمال المخدرات على الاستمرار، ويرتكز هذا العلاخ على فكرة أن أنماط

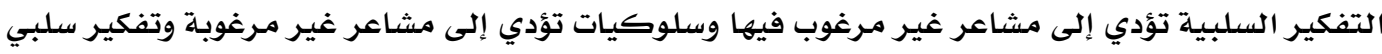
،وهذا الترابط بين الأفكار والمشاعر والسلوكيات هو في صميم العلاخ، الذي يؤكد على فنيات التثقيف النفسي والتخطيط، حيث يقوم المعالج بتثقيف المسترشد حول السلوكيات والحالات الطارئة (المكافآت

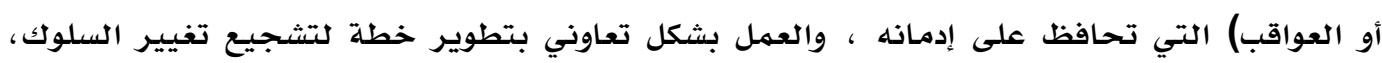

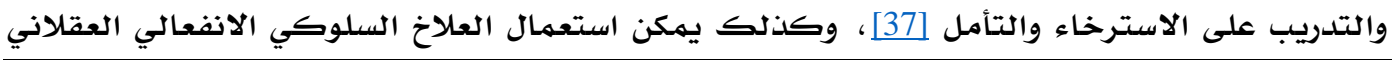
Al-Qraghuli, H. (2019). The defeatist behaviors of addicts in adolescence from the point of view of teachers: the causes and Counseling processors. Journal Port Science Research, 2(1), 11-41. 
يضع تركيزاً أقل على السلوكيات وأكثر على وجهات نظر الفرد بدلاً من التركيز على (REBT,2015) الأفكار، ويركز العلاخ على معتقدات المسترشد لمكافحة هذه المعتقدات الخاطئة ، ومعالجة تأثيرات

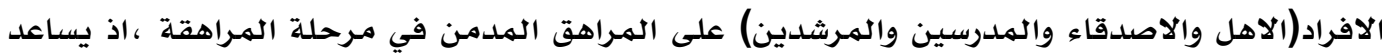
المراهقين على معرفة كيفية توصيل أفكارهم وعواطفهم وسلوكياتهم الشخصية ويقلل من ردود الفعل

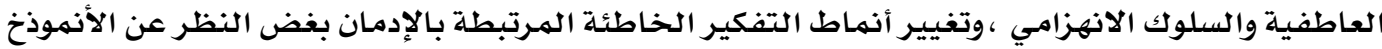

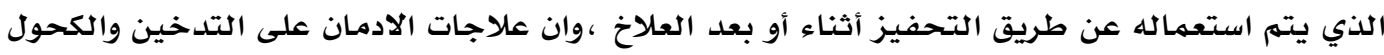

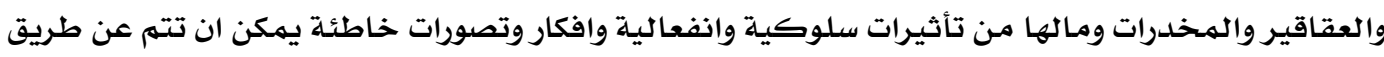
الارشاد الفردي والجمعي وخيارات العلاخ المحدد وبرامج المعالجة البيتية والمدرسية وبرامج الوقاية والصحة النفسية والسلوكية واعادة التأهيل [38] وان دور المرشد النفسي-التريوي في استعادة توازن المراهقين والشباب المدمنين وتعديل سلوكياتهم والعمل على تغييرها وتقديم الدعم النفسي والعاطفي

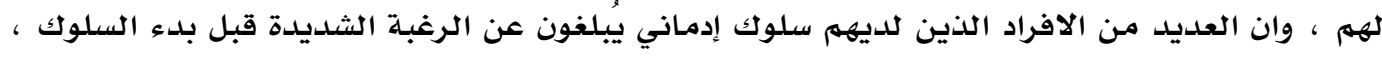

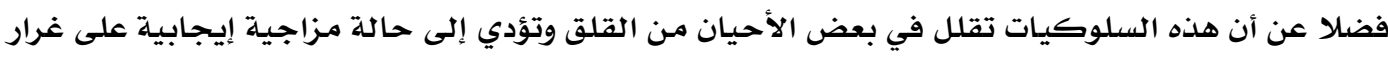

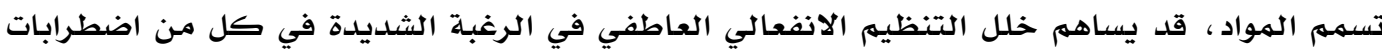

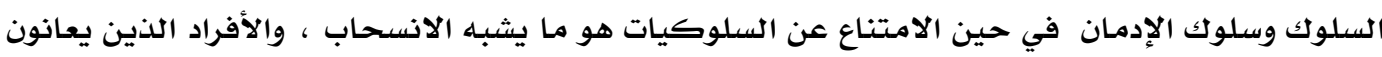
من سلوك إدماني او الذين يعانون من اضطرابات تعاطي المخدرات يسجلون درجات عالية في في مقاييس

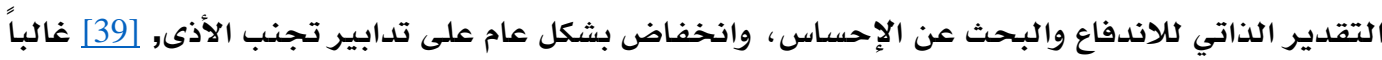

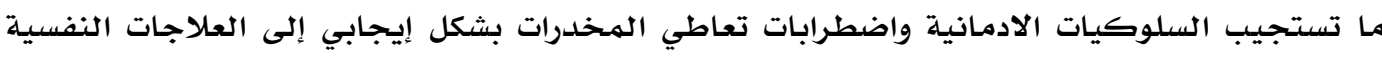

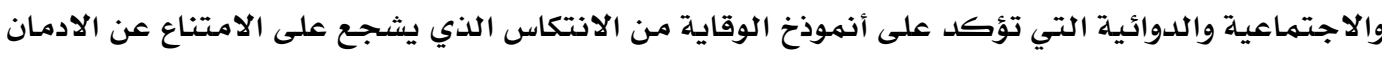

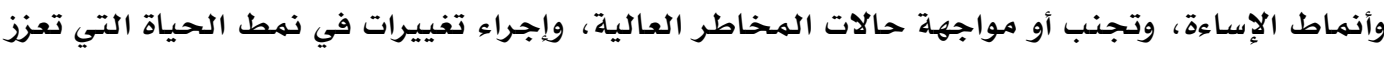
السلوكيات الصحية والعلاجات النفسية والاجتماعية الناجحة ويكون التأكيد فيها على استراتيجيات

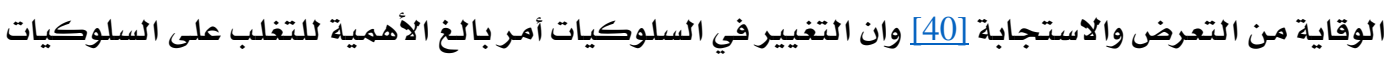

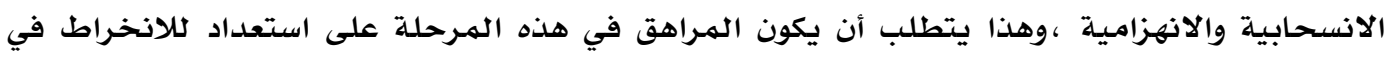

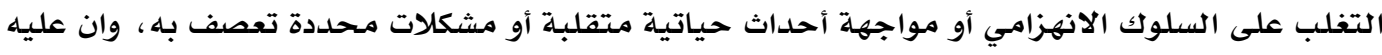

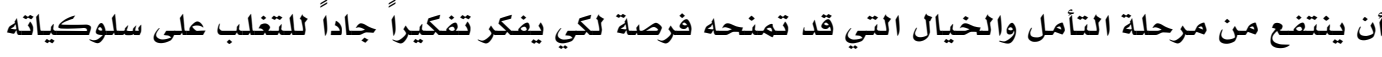

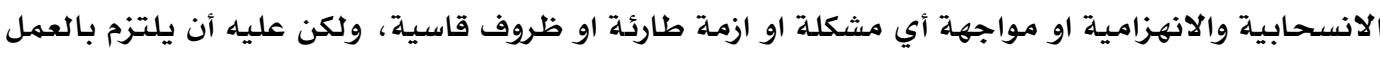

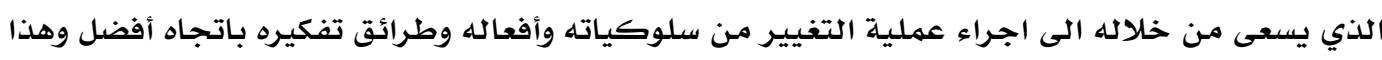
يتطلب منه القيام ببعض الاجراءات حتى يتغلب على المشكلات والمواقف التي تشكل له الاحباط والشعور

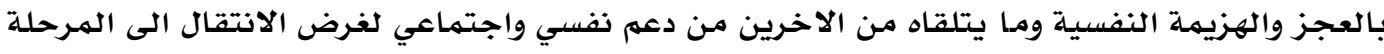

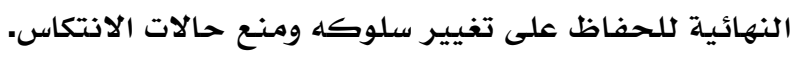

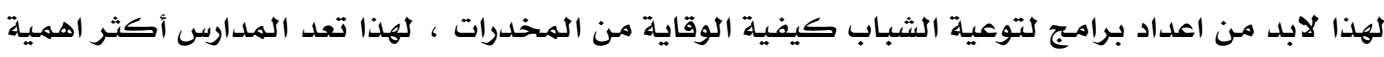

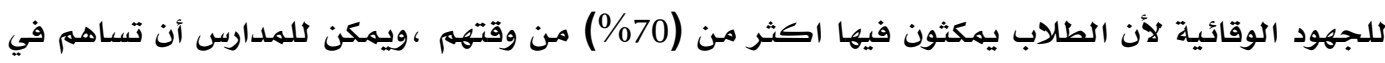

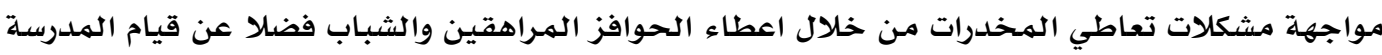

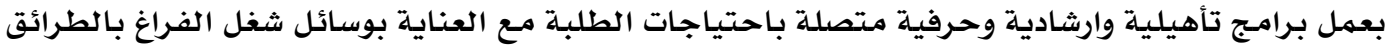

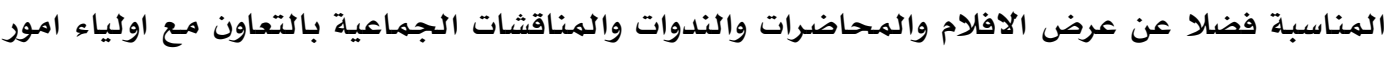


الطلبة [41]، وان البرامـج الارثادية الوقائية تتطلب التخطيط والتنظيم وتعليه وتدريب الطلاب على مواجهة المشكلات والضغوط واتخاذ القرارات المناسبة ومنحهم فرصدة لاختيار بدائل الحلول لهذه المشكلات بالتعاون مـع مرشدي الصفوف من المدرسين واولياء الامور والادارة المدرسية والصححة المدرسية والانتقال من الارثـاد الفردي الى الارشـاد الجمعي ، فضلا عن استعمال طرائق واسـاليب عديدة منها العلاخ

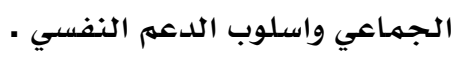

ثالثا: النظريات التي فسرت السلوك الانهزامي والادمان تم الاطلاع على بعض النظريات السلوكية والهعرفية التي اكلت على أهمية السلوك الانساني الذي يتصف بالتعقيد وأنه عبارة عن تراكم مجموعة من الخبرات عبر محطـات عمـر الفرد المختلفة فمن هنا كـان لازمـاً على علماء السلوك وضع وصياغة مجموعة من المعايير التي يمكن الاعتماد عليها لفهم طبيعة السلوك وتفسيره والحكم عليه بالسلبية أو الإيجابية، أي بالسواء أو عدمـه، والسلوك السوي هو مـا يتلاءم مـع مـا نرغب فيه، وما نعتقد انه صحيح ، بينما يكــون الـشاذ نقيض ذلك]ـ[42] والسؤال الذي يتبادر الى الذهن هو كيف ينشأ السلوك المضطرب أو السيء أو الغير سوي؟ كلإجابة على التساؤل نجد أن السلوك السوي والسيء والانهزامي يعزز بالإثابة والهكافأة التي يتلقاها الأطفال والمـراهقين والشباب مـن جانب الآباء والمربين والمعلمين خلال العملية التربوية والتعلمية، على الرغم من تباين آراء المنظرين واختالاف وجهات نظرهم وهي وجهات نظرية رئيسة اعتمدها مجموعة من الباحثين الذين تناولوا السلوك الانهزامسي للمدمنين في مرحلتي الهراهقة والشباب بالدراسة والتحليل وهذه النظريات مـا يأتي: نظرية البرت الليس (Albert Ellis) وقد رأى (البـرت أليس، 1957) أن الافكار اللاعقلانية هي أفكار لا منطقية، يحكم الفرد خلالها على الأحداث في أغلب الظروف، وتتمثل بالقبول المطلق، والكفاءة التامـة وعدم التسامـح وتعظيهم الأمور والسلبية [43] ، والحساسية الزائدة والانهزامية والاتكالية والعجز عن التخلص من الماضي والاهتمام الزائد بالآخرين

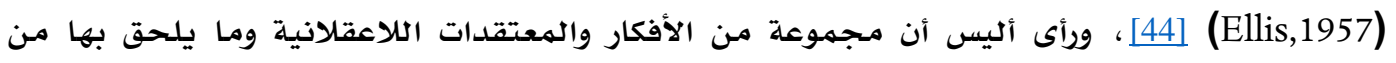
افتراضات تكون هي المسؤولة عن معظم الاضطرابات العاطفية لأنه عندما يتقبل الناس الاضطرابات والانحرافات التي تنطوي عليها الأفكار اللاعقلانية وذلك فإنهم يميلون لكي يصبحوا مكبوتين، وعدوانيون، ودفاعيون وقلقون ،وشاعرين بالذنب، لديهم سلوك انهزامي وغير فعالين، ومنطوين على أنفسهم وغير سعداء (Ellis,1980) وإن الأفكار الكلاعقلانية تترك آثار عميقه على تنظيهم شخصية الفرد وقدرته على التفاعل الاجتماعي وتضعف اتزانه الانفعالي وينتابه إحساس بعدم الراحة والتهديد ،وشكوى من الوساوس ،ويرافق ذلك قلق واحساس بالعزلة فضلا عن تصلب وانغلاق المعتقدات وجمودها وهزيمة

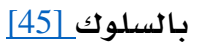
نظرية ارون بيك (Aron Beck) ظهرت هذه النظريـة على يد ارون بيك على حقيقة مؤداها أن لكل فرد افكاراً وتوقعات ومعان وافتراضات عن الذات وعن الاخرين وعن العالم الهحيط بـه وركز بيك على دور العمليات العقلية بالنسبة للدوافع والانفعالات والسلوك حين تتحد الاستجابات الانفعالية والسلوكية الخاصة بشكل ما عن طريق كيفية ادراكه وتفسيره والمعنى الذي يعطيه لحدث ما والعهل على تغيير هذه ا"لأفكار السلبية بأخرى ايجابية عن طريق اعادة تشكيل مدركاته حتى تيسر له التغيير في سلوكا ورأى (بيك 2000) أن الشخص قد يكون غير مدرك تماما للأفكار التلقائية التي تؤثر كثيراً على أسلوب Al-Qraghuli, H. (2019). The defeatist behaviors of addicts in adolescence from the point of view of teachers: the causes and Counseling processors. Journal Port Science Research, 2(1), 11-41. 
المريض وشعوره ومدى استمتاعه بخبراته، غير أنه يستطيع بشيء من التدريب أن يزيد إدراكه لهذه

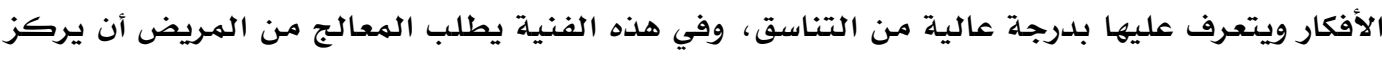

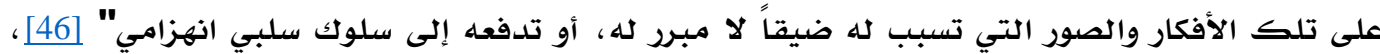
والعلاخ المعرفي السلوكي هو أحد الأساليب العلاجية الحديثة ، وهناك العديد من البرامج التربوية المضادة للإدمان في المدرسة اذ تستعمل عديد من الاساليب الواعدة للوقاية من الادمان على التدخين

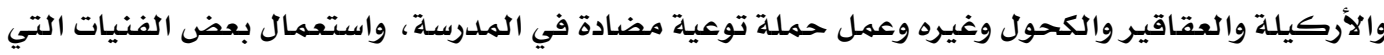

يمكن أن تساعد المسترشدين على تحديد أفكارهم التلقائية السلبية، ومن أشهر هذه الفنيات: O "طريقة مناقشة أحداث الخبرات الانفعالية، واستخدام التخيل لإعادة الخبرة الانفعالية".

O فنية المراقبة الذاتية: " (The Technique of Self-Monitoring) م "فنية تدفق وقف الأفكار: "Idea's Termination Technique) اذ ان المسترشد يقوم ببساطة

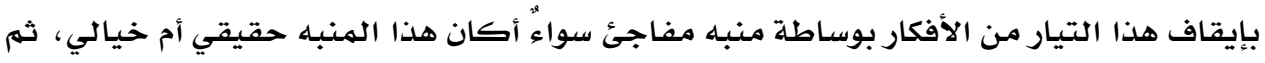

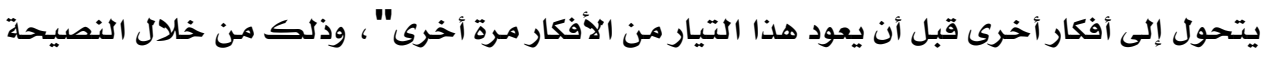
التي يتم توجيهـا للمسترشد بشكل متكرر. هنية التدريب على التحصين الذاتي عن طريق المناقشة الصريحة والحوار التربوي في تقديم

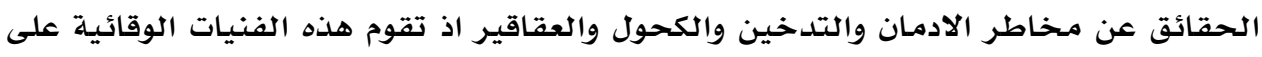
مبدأ التحصين النفسي. ه الافادة من البرامج التوعية في وسائل الاعلام التي تتضمن تعليم المراهقين والشباب كيفية خفض حالات الاعتياد والادمان وانعكاس مظاهره ومخاطره على الصحة الجسمية والنفسية، ليركية وتقديم الاستشارة الارشادية والنفسية للتوقف وعدم استخدام الادمان والكحول والتدخين طريقة للتجنب والانسحاب او الانهزام الذي يصدر عنهم، والعمل على اعداد برامج بعنوان مساعدة المدمنين او المدخنين لوقف الادمان وحثهم على المراجعة النفسية.

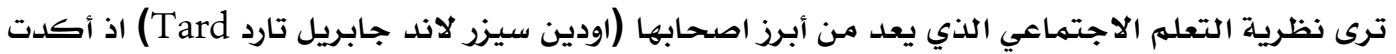
هذه النظرية على ان سلوكيات الانسان تكون متعلمة من الاخرين عن طريق الاختلاط والمحاكاة ، وتفسر هذه النظرية تعاطي المخدرات والادمان عليها بانه سلوك متعلهم ناتج عن مخالطة المتعاطي للجماعة المرجعية ، بحيث ان الجماعة تدعم هذا السلوك لتشعر بان المتعاطي أحد أعضائها الذين

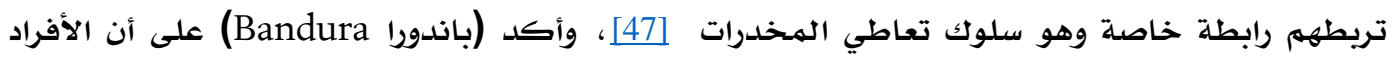

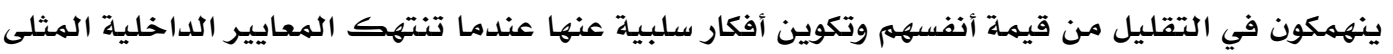
من جراء ارتكابهم أخطاء شخصية ملموسة أو غير ملموسة يصل بهم الامر لمعاقبة الذات ونزعة عقاب

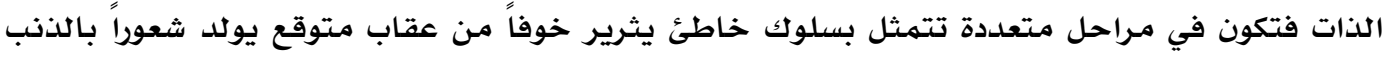
فيحصل السلوك الانهزامي [48]. وتفترض نظرية التعلم الاجتماعي أن تعاطي الخمر والعقاقير وإدمانها سلوك يتعلمه الشخص الذي يشعر الشعرامي

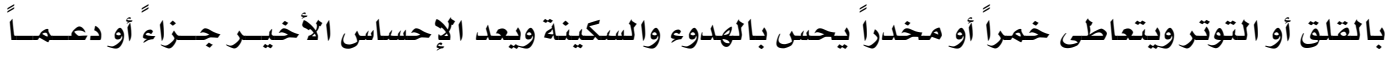

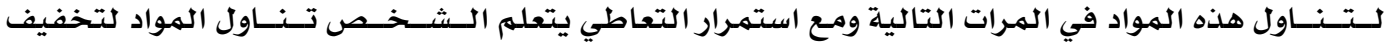
آثار الامتناع المزعجة ،وأوضح أصحاب هذا الاتجاه مبدأ السلوك الإدماني من ان التدعيم الإيجابي يبني 
عادة قوية هي عادة اشتهاء أي عقار ومن آثار تدعيم ذلك وجد أنه قد نشأت عادة التماس العقار بوصفها

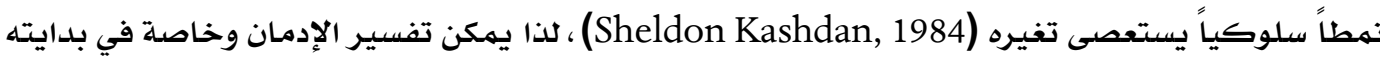
من خلال عملية النمذجة [50]، وباللجوء إلى المخدرات نجد أن سمات الإكتئابية والأنسحابية والانطوائية التي تتسم بها شخصية المدمن بدرجات متفاوتة تتحول إلى شيء مغاير. لذا تم تبني الاطار التكاملي الذي اشتمل على النظريات المعرفية والسلوكية ونظريات التعلهم الاجتماعي

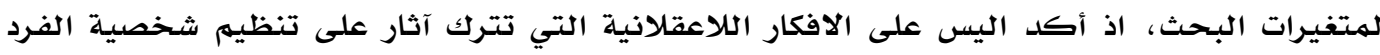
واحساسله بالعزلة وانغلاق المعتقدات الاجتماعية والفكرية وهزيمة السلوك، بينما أكد بيك دور العلميات العقلية بالنسبة للدوافع والانفعالات والسلوك اذ تؤثر الافكار السلبية على الفرد وتدفعه الى سلوك سلبي انهزامي، فضلا عن تأكيد على دور العلاخ المعرفي السلوكي للوقاية من الادمان عن طريق فنيات علاجية، بينما ترى نظرية التعلم الاجتماعي لباندورا التي اكدت على ان سلوكيات الفرد تكون متعلمة

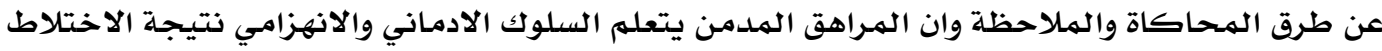
مـع الجماعة والتعزيز الذي يحصل عليه الفرد في محلة المراهقة والشباب.

\section{2. منهجية البحث واجراءاته \\ تم اتباع المنهج الوصفي، وذلك لملاءمته لطبيعتها.} إجراءات البحث: تتضمن الاجراءات المناسبة: مجتمع البحث وعينته وتحديد أدواته واستخراخ خصائصها

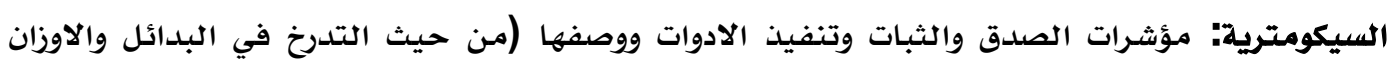
واوساطها الفرضية) والطرق الإحصائية المتبعة في تحليل البيانات.

مجتمع البحث وعينته: يتكون مجتمع البحث الحالي من المدرسين في المرحلة المتوسطة والثانوية

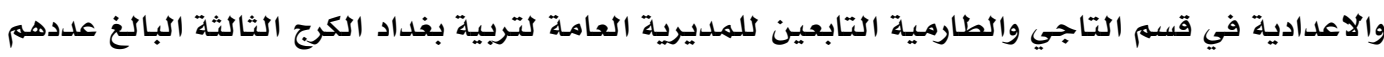

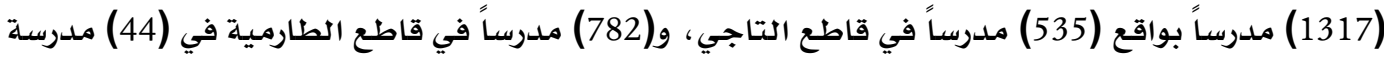

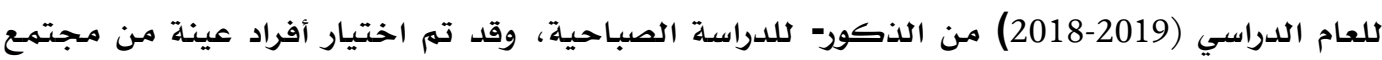

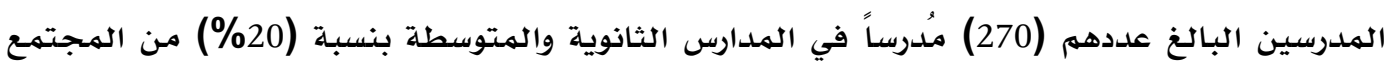
الكلي للبحث.

أداتا البحث: وقد اشتملت على استبانتين مفتوحة ومغلقة، وقد تضمنت أسئلة مفتوحة وجهت الى افراد العينة من المدرسين، والاستبانة تحتوي على مجموعة من الأسئلة والاستفسارات المتنوعة الموضوع التي يجيب عليها المبحوث نفسه وبالشكل الذي يعني متطلبات الحصول على البيانات والمعلومات الخاصة لماتل بمشكلة البحث والإجابة على أسئلة الاستبانة التي يحدد عددها بحسب طبيعة البحث تتهم من خلال عدة

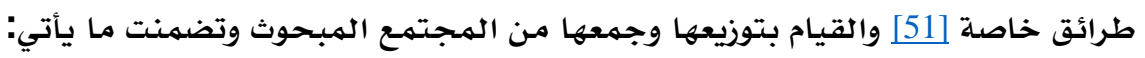

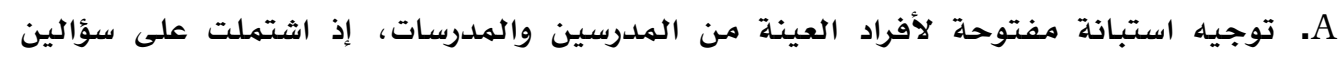

$$
\text { (ملحق1) }
$$

B في ضوء تحليل إجابات العينة الاستطلاعية على الاستبانة الاستطلاعية ومن خلال الاطلاع على . الأدبيات والدراسات السابقة والخبرة الذاتية تم إعداد وبناء استبانة مغلقة وتوجيها لأفراد العينة 
من المدرسين إذ تضمنت الاستبانة بصورتها النهائية (41) سبباً من أسباب السلوك الانهزامي

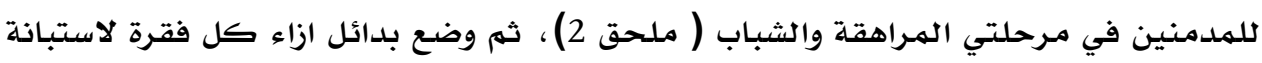

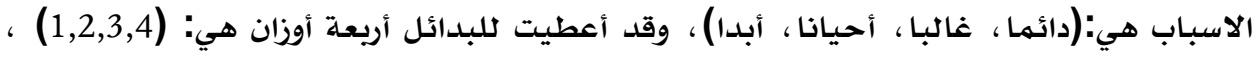

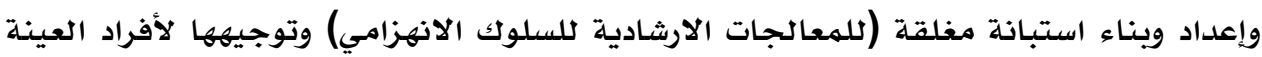

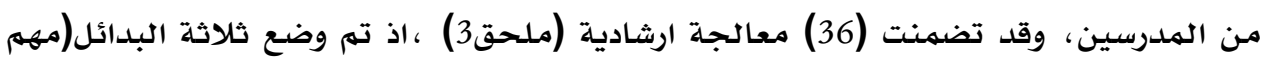

$$
\text { جدا، مهم، غير مهم ) والأوزان (1,2,3). }
$$

الصلدق الظاهري للاستبانتين: تم عرض الاستبانتين على عدد من المحكمين من ذوي الاختصاص في علم النفس والإرشاد النفسي والقياس والتقويم (ملحق4) لمعرفة مدى صلاحية فقرات الاستبانتين وقياس أسباب السلوك الانهزامي وتحديد المعالجات الارشادية، وتم الأخذ بالملاحظات والتعديلات الطفيفة ملاكية

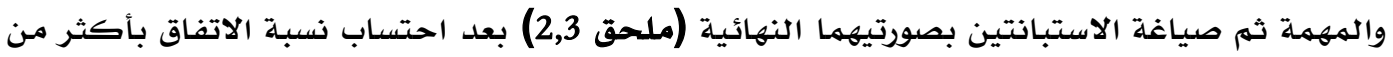

$$
\text { (\%) ملى صلاح الفقرات. }
$$

ثبات الاستبانتين: يعد الثبات من سمات الاختبار الجيد ، اذ يقصد به أن الاختبار يعطي النتائج نفسها

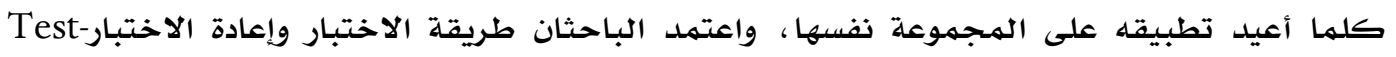

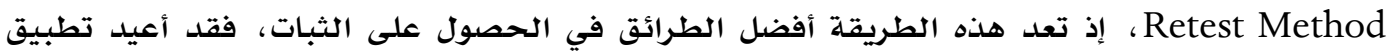

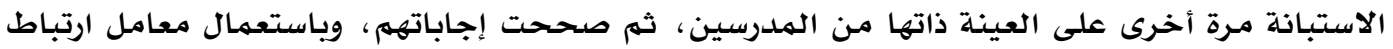

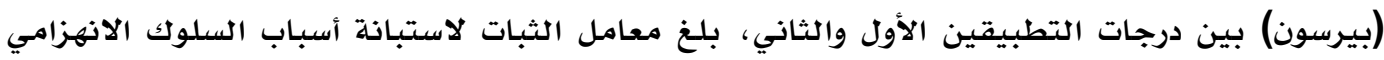
(0,78) ، واستبانة المعالجات الارشادية (0,84). تطبيق الاستبانتين: بعد تحديد عينة البحث الحالي البالغة (270) مدرساً وزعت الاستمارات على أفراد العينة، وتم إيضاح ما هو مطلوب منهم في الاجابة، ثم شرح طريقة الاستجابة على الاستبانتين.

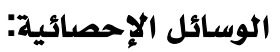

1) استخدمت في البحث الوسائل الإحصائية المناسبة التكرارات (والوسط المرجح * والوزن المئوي).

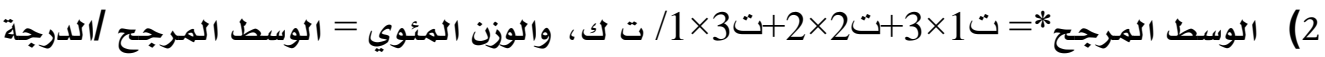
القصوى 1001 3) معامل ارتباط بيرسون:Person -Correlation) أستعمل في استخراخ معامل الثبات بطريقة الاختبار وإعادة الاختبار) (Test - Retest method) .

\section{3. مرض نتائج البحث وتفسيرها ومناقشتها} يتضمن هذا الفصل عرضاً للنتائج التي تم التوصل إليها على وفق أهداف البحث وتفسير هذه النتائج بحسب الإطار النظري ومناقشتها وخصائص المجتمع الذي تمت دراسته في البحث الحالي، ومن ثم

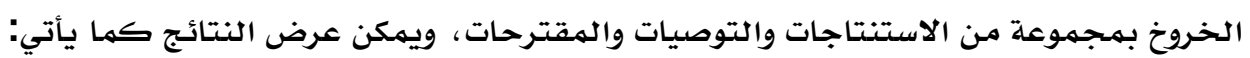
الهدف الأول: التعرف الى أسباب السلوكيات الانهزامية لدى المدمنين في مرحلتي المراهقة والشباب 
من أجل التحقق من هذا الهدف، قام الباحثان باستعمال الوسط المرجح والوزن المئوي في معالجة البيانات ووصف استجابة افراد العينة على الاداة ، واعتبار الفقرة التي تحصل على وسط مرجح أقل من (50، 2) ووزن مئوي(63\%) غير متحققة، وقد تم احتساب الوسط الفرضي بناءً على جمع درجتي بدائل

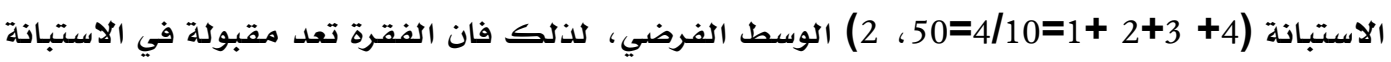

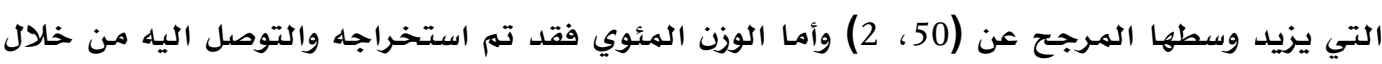

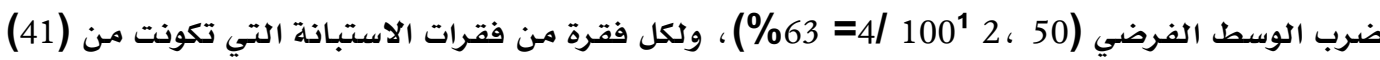
فقرة، وكانت جميع الفقرات متحققة، كما موضح في جدول(1) .

جلدول (1) الرتب والؤساط المرجحة والأوزان المئوية لفقرات استبانة أسباب السلوك الانهزامي

\begin{tabular}{|c|c|c|c|c|}
\hline \multicolumn{3}{|c|}{ 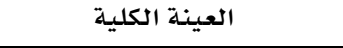 } & \multirow[b]{2}{*}{ 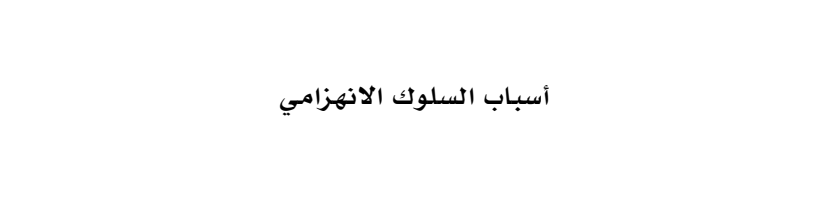 } & \multirow{2}{*}{ الاستبانة } \\
\hline | الرتبـة & 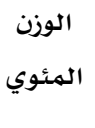 & المرجط - المج & & \\
\hline 1 & 93 & 3,72 & يجد المدمن صعوبة في التركيز على الدراسة او الانتباه لشرح المدرس & 3 \\
\hline 2 & 91.25 & 3,65 & تقلب مزاخ المراهق المدمن بصورة مفاجئة & 4 \\
\hline 3 & 91.25 & 3,65 & ميل المدمن الى الخمول والكسل والنعاس وكثرة التثاؤب & 17 \\
\hline 4 & 90,5 & 3,62 & العقاب والشجار الاسري يشعر المدمن بالسلوك الانهزامي & 35 \\
\hline 5 & 90 & 3,6 & يشعر المراهق المدمن بضعف اتخاذ القرار المناسب & 20 \\
\hline 6 & 89,25 & 3,75 & يشعر المدمن بضعف مستوى الاداء والكفاءة الذهنية & 16 \\
\hline 7 & 89,25 & 3,57 & لديه الرغبة في الهروب من الواقع والابتعاد عن المجتمع & 39 \\
\hline 8 & 89,25 & 3,57 & يخشى المواجهة مـع الآخرين ولا يقبل التحدي & 41 \\
\hline 9 & 88,75 & 3,55 & يشعر بالفشل في المواقف المتأزمة & 36 \\
\hline 10 & 88,75 & 3,55 & يكون المدمن بحالة من الشرود الذهني والللامبالاة داخل الصف & 34 \\
\hline 11 & 88 & 3,52 & يعاني المراهق من السهر وقلة النوم مما يظهر عليه التعب داخل الصف & 8 \\
\hline 12 & 88 & 3,52 & لا يرغب المدمن في التحدث عما يعانيه من مشكلات إلى أحد حفاظا على & 37 \\
\hline 13 & 87,75 & 3,5 & يميل المراهق المدمن الى خداع زملائه في المدرسة والكذب عليهم & 7 \\
\hline 14 & 87,5 & 3,5 & مسايرة الصحبة السيئة وتعلم سلوكيات منحرفة & 19 \\
\hline 15 & 86,75 & 3,47 & يصدر عن المدمن تصرفات طائشة وفوضوية & 23 \\
\hline 16 & 86,25 & 3,45 & ينسحب عن زملائه لان أفكاره لا تتلاءم مـع أفكارهم & 38 \\
\hline 17 & 86,25 & 3,45 & ضعف قدرة المدمن على أدارة ذاته وضبطها في البيئة المدرسية & 30 \\
\hline 18 & 85,5 & 3,42 & ضعف دافعيته للدراسة وشعوره بالفشل المتوقع & 26 \\
\hline 19 & 84,25 & 3,37 & يتمنى أن يشعر بالرضا والسعادة كما يشعر زملائه الاخرين & 12 \\
\hline 20 & 84,25 & 3,37 & شعوره بتدني اعتبار ذاته وقيمته ومكانته & 27 \\
\hline 21 & 83,75 & 3,35 & يميل المدمن الى العنف والعدوان في التعامل مع زملائه & 22 \\
\hline 22 & 83,75 & 3,35 & يفضل الابتعاد عن الأماكن المزدحمة بالناس & 40 \\
\hline 23 & 82,5 & 3,3 & يشعر بالقلق والتوتر في معظم الاوقات & 11 \\
\hline 24 & 82,5 & 3,3 & لا يظهر اهتماما بالأنشطة الرياضية لضعف نشاطه الحركي & 21 \\
\hline
\end{tabular}

Al-Qraghuli, H. (2019). The defeatist behaviors of addicts in adolescence from the point of view of teachers: the causes and Counseling processors. Journal Port Science Research, 2(1), 11-41. 
j. port. sci. res. ISSN: 2616-7441 (Online) ISSN: 2616-6232 (Print) ISSN: $2616-7220$ (USB)

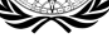

\begin{tabular}{|c|c|c|c|c|}
\hline 25 & 82,5 & 3,3 & تقليد المراهق لسلوكيات والده المدمن & 33 \\
\hline 26 & 81,75 & 3,27 & غالبـا ما يشعر الملدمن بالوحدة والعزلة عن الاخرين & 9 \\
\hline 27 & 81,75 & 3,27 & تسرع المدمن واندفاعه بعصبية زائدة نحو زمـلائه & 25 \\
\hline 28 & 81,75 & 3,27 & يشعر بالتهلديد والخطر في اثناء الاختلاط مـع زملائي & 32 \\
\hline 29 & 81,25 & 3,25 & لا يتهم المدمن كثيرا الى مظهره الخارجي & 5 \\
\hline 30 & 81,25 & 3,25 & يلجأ الى التحايل والغش للحصول على درجات النجاح لضعف مستواه & 6 \\
\hline 31 & 80,5 & 3,22 & تظهر على المدمن المـراهق علامـات السلوك المنـحرف & 15 \\
\hline 32 & 80 & 3,2 & يشعر المدمن المـراهق بـانه سريـع الغضب لأتفه الاسبـاب & 14 \\
\hline 33 & 80 & 3,2 & الاصطدام المفاجئ مـع المدرسين & 24 \\
\hline 34 & 80 & 3,2 & يميل المـراهق الى حل مشكلاته عن طريق احلام اليقظة & 28 \\
\hline 35 & 78,75 & 3,15 & الاحساس بالرضا والسرور والتعالي والضحك والبكاء في فترات متفاوتة & 18 \\
\hline 36 & 78 & 3,12 & يميل الى الانسحاب من المواقف الصعبـة والمـخجلة & 10 \\
\hline 37 & 75 & 3 & تعبير المدمن عن مشاعر الغيرة والغضب والتنفيس من الاحبـاط & 13 \\
\hline 38 & 70,5 & 2,82 & يرتكب الهـراهق سلوكيات السرقة داخل الصف بين فترة واخرى لغرض الحصول على المال & 1 \\
\hline 39 & 67,75 & 3,07 & يميل المدل الى الافراط بالتدخين داخل المدرسة & 31 \\
\hline 40 & 65,5 & 2,62 & تسلطية المدرس وميلـ المستمـر إلى مهـارسـة العقاب مـع المـراهق المدمن & 29 \\
\hline 41 & 63 & 2,52 & من السهل ان يشعر المدمن بالهزيمـة في الحوارات والمناقشات الجماعية & 2 \\
\hline
\end{tabular}

يلحظ من الجدول (1) أن الفقرة التي احتلت المرتبة الأولى بحسب وسطها المرجح (3,72) ووزنها المئوي

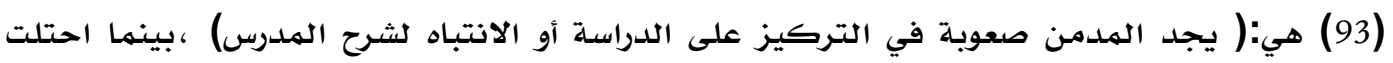

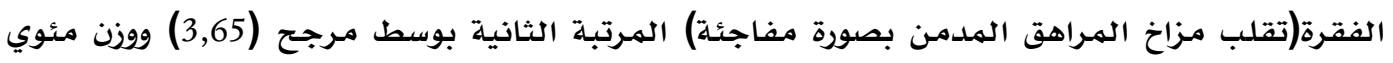

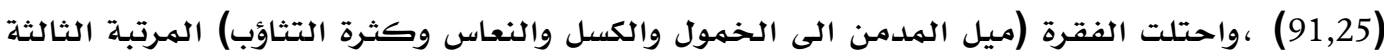

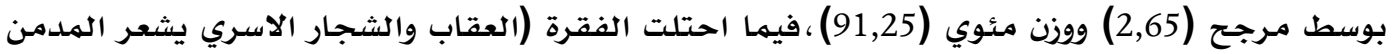

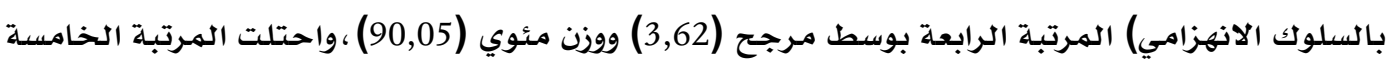

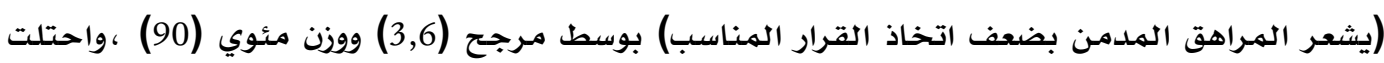

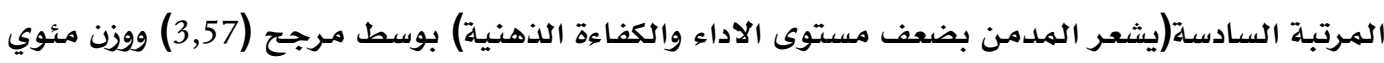

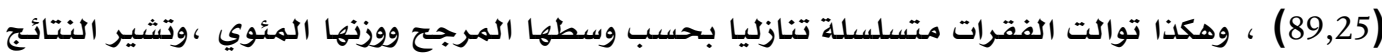
أن المـراهق المدمن نتيجة لإدمانه على مادة من المواد المخحدرة انه يفقد التركيز والتشتت وعدم الانتباه وتغير مـزاجـه بصورة مفاجئلة مها يجعله يشعر بالخمول والكسل وضعف الاداء المدرسي والكفاء الذاتية، فضلا عن الخلافات الاسرية في البيت الى تنعكس على نشاطه الملدرسي وهذه سلوكيات تدل على انهزام

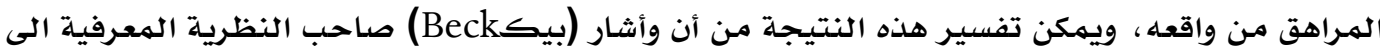
أن الخبرات الحياتية التي يمر بها الفرد تستهمد دلالتها الضاغطة او المكتئبة أو الانهزامية من خلال علاقتها بأفكار الفرد أي مـن خلال ادراك الفرد لها أو للواقع بشكل سلبي وبناءً على هذه الافكار يبدأ الفرد في مشاعر انفعالية يتفق معها وسلوكيات تدعمها ، وانّ افكار الهراهقين والشباب وتصوراتهمم تؤثر على

القره غولي، حسن احمد سهيل. (2019). السلوكيات الانهزامية للمدمنين في مرحلة المراهقة والشباب من وجهة نظر

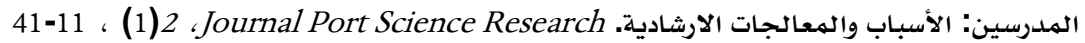


عواطفهم وسلوكهم فتكون هذه الافكار مزعجة لهم وتفقدهم التركيز وأثار أليس Ellis أن الافكار الكلاعقلانية تدفههم الى سلوك سلبي انهزامي. أن الافكار اللاعقلانية هي أفكار لا منطقية، يحكم الفرد خلالها على الأحداث في أغلب الظروف، وتتمثل بالقبول المطلق، والكفاءة التامـة وعدم التسامـح وتعظيم الأمور والسلبية، والحسـاسية الزائدة والانهزامية والاتكالية والعجز عن التخلص من الماضي والاهتمام

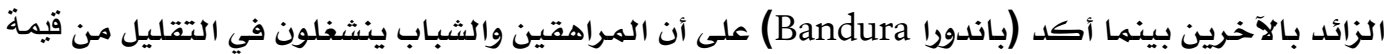
أنفسهم وتكوين أفكار سلبية عنها عندما تنتهك معايرهم الداخلية المثلى نتيجة لارتكابهم أخطاء شخصية ملموسـة أو غير ملموسـة مما يؤدي بهم الى معاقبة ذواتهم فتكون في مـراحل متعددة تتمثل بسلوك خاطئ يثير خوفاً من عقاب متوقع يولد شعوراً بالذنب فيحصل السلوك الانهزامي. الهلف الثاني: التعرف الى الهعالجات الارشادية للسلوكيات الانهزامية لدى الهدمنين في مرحلتي المـراهقة والشباب من وجهة نظر المدرسين. من أجل التحقق من هذا الهدف، قام الباحثان باستعمال الوسط الهـرجح والوزن المئوي في معالجـة البيانات ووصف استجابة افراد العينـة على الاداة ، واعتبار الفقرة التي تحصل على وسط مـرجـح أقل من (2) ووزن مئوي (67\%) غير متحققة، وقد تم احتساب الوسط الفرضي بناءً على جمـع درجتي بدائل الاستبانة (3+2+1=2/6=2) الوسط الفرضي، لذلك فان

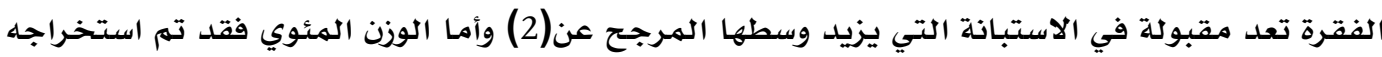

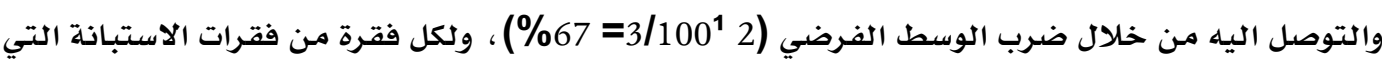
تكونت من (36) فقرة وكانت جميع الفقرات متحققة ، كما موضتح في جدول(2) . جلسول (2) الرتب والأوساط الهرجحة والؤوزان الهئوية لفقرات استبانة المعالجات الارثادية للسلوك الانهزامي

\begin{tabular}{|c|c|c|c|c|}
\hline \multicolumn{3}{|c|}{ 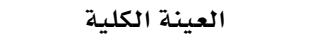 } & \multirow[b]{2}{*}{ المعالجات الارشادية للسلوك الانهزامي } & \multirow{2}{*}{ الاستبر } \\
\hline الرتبـة & 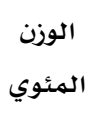 & 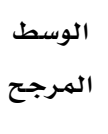 & & \\
\hline 1 & 95 & 2,85 & تنمية الوعي الذاتي للمراهقين وإبراز معلومات حقيقية ومتوازنة حول مضار & 6 \\
\hline 2 & 94 & 2,85 & الاشراف الواعي في عدم اهمال الابناء وتركهم فريسة للصحبة السيئة & 5 \\
\hline 3 & 92 & 2,76 & الوقاية وبناء الحصانة الذاتية والمجتمعية هي أفضل استراتيجية لمواجهة & 1 \\
\hline 4 & 91,66 & 2,75 & التعرف الى اصدقاء الابناء وزملائهم ومعرفة كيفية قضاء الوقت معهم & 4 \\
\hline 5 & 90,66 & 2,72 & الاستعانة بالأصدقاء والزملاء المؤثرين في نشر حملة البرامج المدرسية ضد & 35 \\
\hline 6 & 90,66 & 2,72 & العمل على حماية المراهق المدمن من الانتكاس والرجوع الى حالة الادمان & 36 \\
\hline 7 & 90 & 2,7 & الاعتناء بتحسين العلاقة بين الوالدين والابناء وتوفير احتياجاتهم النفسية & 2 \\
\hline 8 & 90 & 2,7 & اعداد البرامجج التريوية والتوعوية والتثقيفية في المدرسة عن مضار التدخين & 13 \\
\hline 9 & 90 & 2,7 & استخدام أسلوب المدل والثناء على الطالب امام زملائه & 20 \\
\hline
\end{tabular}

Al-Qraghuli, H. (2019). The defeatist behaviors of addicts in adolescence from the point of view of teachers: the causes and Counseling processors. Journal Port Science Research, 2(1), 11-41. 
j. port. sci. res. ISSN: 2616-7441 (Online) ISSN: 2616-6232 (Print) ISSN: $2616-7220$ (USB) $\Rightarrow 2$
Journal port Science Research Available online www.jport.co Volume: 2, No: 1

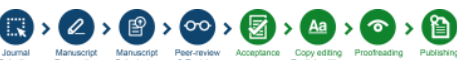

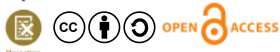

\begin{tabular}{|c|c|c|c|c|}
\hline 10 & 90 & 2,7 & تدريب المراهق مهارات مقاومة تأثير الاصدقاء السيئين & 33 \\
\hline 11 & 90 & 2,7 & 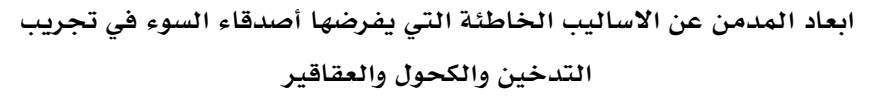 & 34 \\
\hline 12 & 90 & 2,7 & استعمال أسـاليب الارثاد الديني الروحي لتغيير سلوكيات المدمن & 30 \\
\hline 13 & 89 & 2,67 & اسلوب وقف الافكار اللاعقلانية للطالب المدمن بصورة فورية & 12 \\
\hline 14 & 88,33 & 2,65 & تقديم خلدمات ارثادية تقوم على مساعدة المراهقين على التوقف والامتناع & 15 \\
\hline 15 & 88,33 & 2,65 & اسلوب المشاركة الفعالة لأوليـاء أمور المتنمـرين في ايجاد الحلول & 16 \\
\hline 16 & 88,33 & 2,65 & اسلوب العمل على تزويد المدمن بالبدائل واقناعه بها & 27 \\
\hline 17 & 88,33 & 2,65 & تدريب المـراهق على التأمل والتركيز ومممارسة الرياضة لتحسين المزاخ & 28 \\
\hline 18 & 88,33 & 2,65 & مسـاعدة المـراهق المدمن على التخلص من الألم النفسي ومعاناته & 29 \\
\hline 19 & 87,33 & 2,62 & مسـاعدة الهـراهق المدمن التحدث عن مشكلته الادمانية بصراحـة & 32 \\
\hline 20 & 87,33 & 2,62 & عدم فتح المـجال امـام الابناء للبحث عن التعويض خارخ الاسرة & 3 \\
\hline 21 & 87,33 & 2,62 & اعداد برامـج وقائية وإصلاحية مججتمعية تسهم في بناء قدرات الشبـاب الفكريـة & 7 \\
\hline 22 & 87,33 & 2,62 & تدريب المـراهقين على استراتيجيات الامتتاع والمقاومـة والمواجهة وعدم & 8 \\
\hline 23 & 86,66 & 2,6 & استعمال اسلوب الاقناع المنطقي مـع المـراهقين الملدمنين للتخلص من آثار & 24 \\
\hline 24 & 86,66 & 2,6 & اسلوب الاندماخ والتفاعل مـع الاخرين & 18 \\
\hline 25 & 85,66 & 2,57 & استخدام أسلوب المواجهة الفعالة في ضبط الذات والسيطرة على السلوكيات & 14 \\
\hline 26 & 85 & 2,55 & اسلوب التدعيم النفسي والأسـري والمدرسي & 17 \\
\hline 27 & 85 & 2,55 & 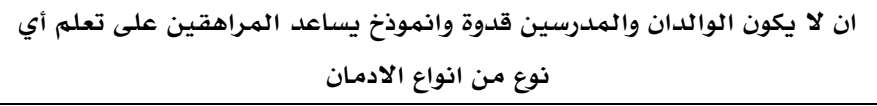 & 10 \\
\hline 28 & 84 & 2,52 & اسلوب الحوار والمناقشة الصريحة وتقديم الحقائق والادلة عن مضار التدخين & 11 \\
\hline 29 & 84 & 2,52 & اسلوب الاهتمام والاسري المدرسي بالمراهق المدمن وإحسـاسـه بقيمته ومكانته & 25 \\
\hline 30 & 83,33 & 2,5 & استخدام أسلوب التهدئة والطمأنة الذاتية في امكانية التخلص من الادمان & 22 \\
\hline 31 & 83,33 & 2,5 & اسلوب تعديل التصورات الخاطئة للمدن حول الادمان بانه يساعد على الهروب الواقع & 26 \\
\hline 32 & 82,33 & 2,47 & أسلوب تصحيح الأخطاء بصورة مباشرة & 23 \\
\hline 33 & 81,66 & 2,45 & اسلوب التعاقد السلوكي وتقديم التعزيز بشكل منظم & 21 \\
\hline 34 & 80,66 & 2,42 & أسلوب التوجيه في الوقت المناسب داخل الصف & 19 \\
\hline 35 & 80 & 2,4 & استعمال فنيات الاستبصار واظهار الدليل وتعزيز دورهم الاجتماعي & 9 \\
\hline 36 & 77,33 & 2,32 & استعمال أسلوب تعزيز التغيير الاجتماعي للمدمن & 31 \\
\hline
\end{tabular}

يلحظ من الجدول (2) أن الفقرة التي احتلت المرتبة الأولى بحسب وسطها المرجح(2,85) ووزنها المئوي

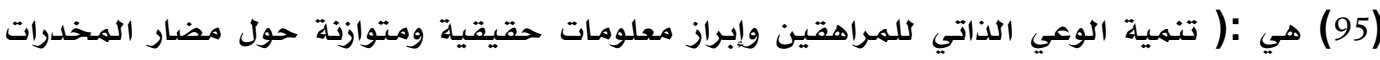

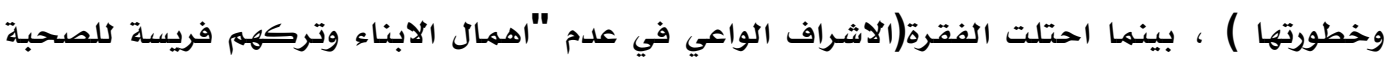




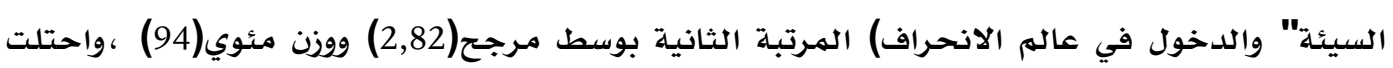

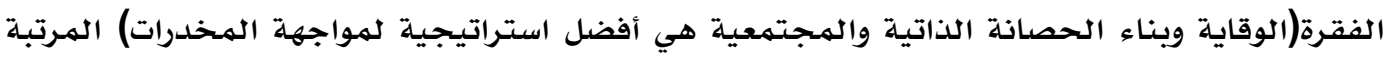

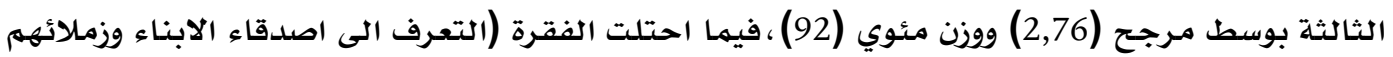

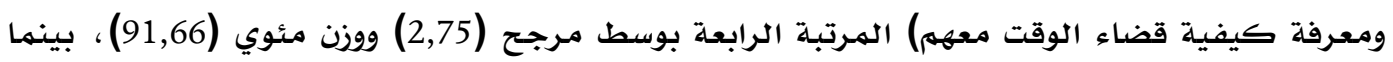

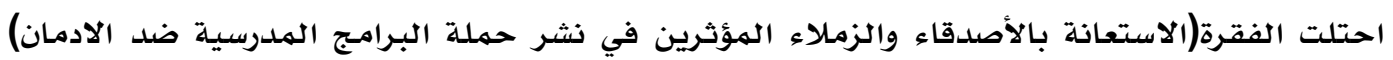

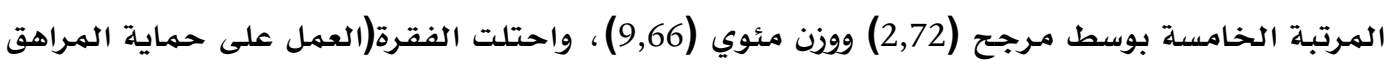

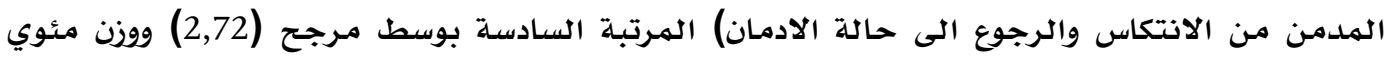
(90,66)،وقد أشارت نتائج البحث الى ان ضعف الوعي الذاتي للمراهق وضعف قدرته على الانتباه لنفسه

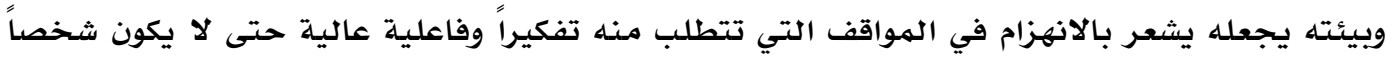
منقادا لغيره من الصحبة السيئة وتقليدهم كما يرى باندورا من أن سلوكيات الفرد تكون متعلمة من الاخرين عن طريق الاختلاط والمحاكاة ، وتفسر هذه النظرية تعاطي المخدرات والادمان عليها بانه

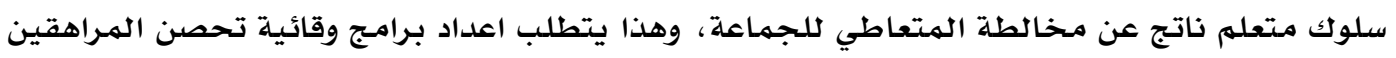
من الوقوع في الادمان مما يجعلهم يهريون من واقعهم بطرائق سلبية ومساعدتهم على عدم الانهزام الى لى

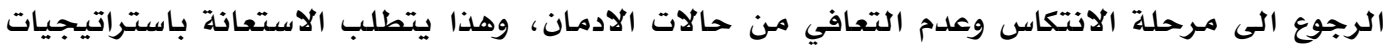
وفنيات العلاخ المعرفي السلوكي كما اكد على ذلك بيك وأليس في التخلص من الافكار اللاعقلانية

\section{4. - 4. الاستنتاجات}

في ضوء نتائج البحث الحالي يمكن استنتاخ ما يأتي:

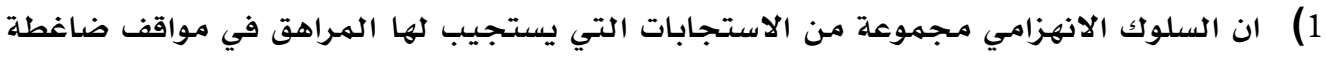

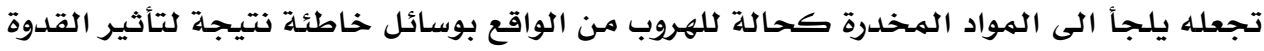

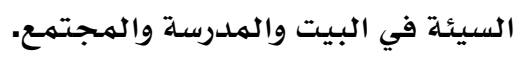

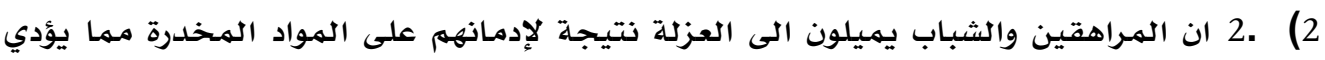
ذلك الى ضعف انتاجيتهم وادائهم المدرسي والقيام بسلوكياتهم منحرفة اتجاه أنفسهم واتجاه

$$
\text { الاخرين. }
$$

3) 3.ان المراهقين والشباب في المرحلة المتوسطة هم بحاجة الى خطط وبرامجج ارشادية وتوعوية تعمل على تحصينهم من الوقوع بالإدمان وانعكاس ذلك على الفكار الفارهم وسلوكياتهم ومشاعرهم تجاه الاخرين أو تكون هذه السلوكيات مخالفة للمعايير والانظمة التربوية والاخلاقية. 


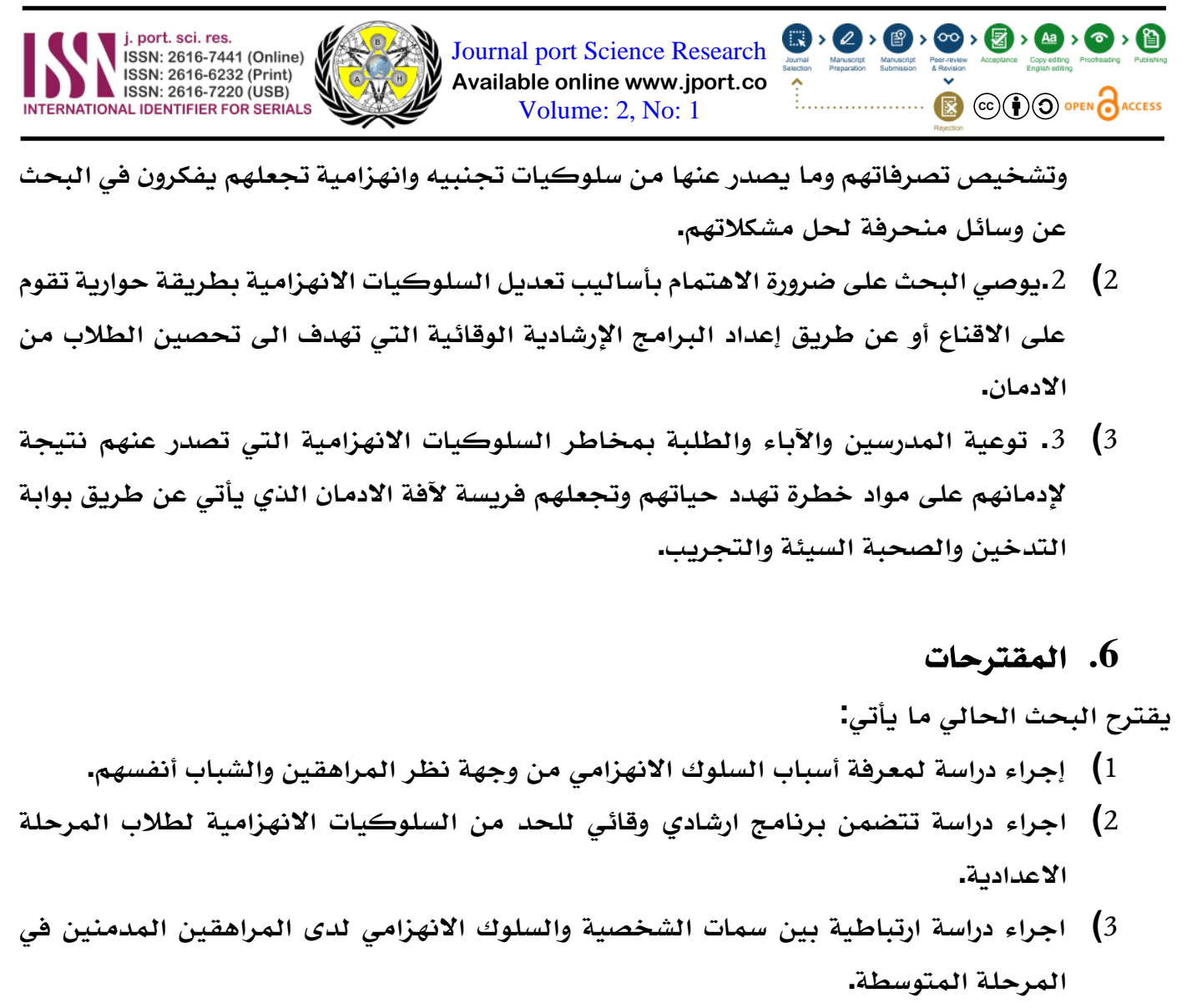

\section{References}

[1] Abu Ajwa, M. (2012). در اسة مقارنة لبعض سمات الثخصية لاى مدمني ومروجي المخدرات و العاديين > (Master Thesis), Faculty of Education, Islamic University, Gaza. (p.2). Retrieved from https://search.mandumah.com/Record/693600

[2] Badawi, A.I, \& Saadat, M. F. (2016). الآثار الصحية والنفسية لتعاطي شباب الجامعة للمواد المخدرة > Conference of the Faculty of Sharia VI: drug abuse, causes, effects and treatment from an Islamic perspective, social and legal. Faculty of Sharia at An - Najah National University. Cairo Egypt. Retrieved from https://repository.najah.edu/handle/20.500.11888/10348

[3] sharbji, Wassen Abdul Hussein. (2010). المخدر ات و المجتمع تحديات منبادلة > Center for Research on Childhood and Motherhood, Diyala University, Ministry of Higher Education and Scientific Research, p14.

[4] Tahawi, J. (2006). ادمان الثباب على المخدرات الاسباب> >. Abstract: Summaries of summaries of the University Youth Conference and the Scourge of Drugs, Zarqa University, Jordan.

[5] Hoffman, S. I., \& Strauss, S. (1985). The development of children's concepts of death. Death Studies, 9(5-6), 469-482. https://doi.org/10.1080/07481188508252538

[6] Andreasen, N. C., \& Olsen, S. (1982). Negative v Positive Schizophrenia: Definition and Validation. Archives of General Psychiatry, 39(7), 789-794. https://doi.org/10.1001/archpsyc.1982.04290070025006

القره غولي، حسن احمد سهيل. (2019). السلوكيات الانهزامية للمدمنين في مرحلة المراهقة والشباب من وجهة نظر

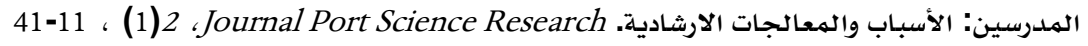


[7] Couture, S. M., Blanchard, J. J., \& Bennett, M. E. (2011). Negative expectancy appraisals and defeatist performance beliefs and negative symptoms of schizophrenia. Psychiatry Research, 189(1), 43-48. https://doi.org/10.1016/j.psychres.2011.05.032

[8] Beck, A. T., \& Dozois, D. J. (2011). Cognitive therapy: current status and future directions. Annual review of medicine, 62, 397-409. https://doi.org/10.1146/annurev-med-052209-100032

[9] Michalak, L., \& Trocki, K. (2018). Alcohol and Islam: An Overview. Contemporary Drug Problems, 33(4), 523-562. https://doi.org/10.1177/009145090603300401

[10] Olsen, C. M. (2011). Natural rewards, neuroplasticity, and non-drug addictions. Neuropharmacology. doi.org/10.1016/j.neuropharm.2011.03.010

[11] Ahmed, Ahmed Kamal. and Solomon, Adly. (1963). الخدمة الاجتماعية والمجتمع > Cairo, Modern Cairo Library. https://tinyurl.com/y6qzha39

[12] Mostaghim, A., \& Hathaway, A. D. (2013). Identity formation, marijuana and "the self": A study of cannabis normalization among university students. Frontiers in Psychiatry, 4(DEC) https://doi.org/10.3389/fpsyt.2013.00160

[13] Khalifa, Sarra \& Issawi, Fella. (2018). • ظاهرة تعاطي المخدرات: المفهوم، الأضرار العلاج) Journal of Studies of the University of Ammar Thligi Algwat, Algeria, International.

[14] Peele, S. (1992). The Truth About Addiction and Recovery. In the Truth About Addiction and Recovery (pp. 19-46).

[15] Rikabi. L. Y. (2011). اسباب تعاطي المو اد المخدرة لدى طلبة المرحلة الاعدادية >. Psychological Science, (19), 75-106. https://www.iasj.net/iasj?func=fulltext\&aId=2727

[16] National Institute on Drug Abuse. (2012). Treatment approaches for drug addiction. National Institutes of Health. $\quad$ Retrieved from https://www.drugabuse.gov/sites/default/files/df_treatmentapproaches_1_2016.pdf

[17] Ibrahim, Abdul Sattar. (1998). الاكتئاب ... اضطراب العصر الحديث فهمه وأساليب علاجها . National Council for Culture, Arts and Letters, Kuwait. http://maktabatalfeker.com/upload/239$\% 20 \quad$.pdf

[18] Mohammed, H. H. (2016) الأفكار اللاعقلانية و علاقتها بالسلوك الانهز امي لدى طالبات رياض الأطفال في كلية الأبية >. Journal of College of Education, Wasit,1(24), 321-362. https://www.iasj.net/iasj?func=article\&aId=113800

[19] Najjar, F. (2005). أضواء إسلامية_> Dar Al Fadila Publications, Riyadh (1th). https://archive.org/download/85145/709.pdf

[20] Kieling, C., Baker-Henningham, H., Belfer, M., Conti, G., Ertem, I., Omigbodun, O., ... Rahman, A. (2011, October 22). Child and adolescent mental health worldwide: Evidence for action. The Lancet. https://doi.org/10.1016/S0140-6736(11)60827-1

[21] Spooner, C. (1999, December). Causes and correlates of adolescent drug abuse and implications for treatment. Drug and Alcohol Review. https://doi.org/10.1080/09595239996329

[22] Al-Dmrdash. A. (1982). الإدمان مظاهرهو وعلاجه >. A series of cultural books published monthly by the National Council for Culture, Arts and Letters Kuwait. http://iqra.ahlamontada.com/t1255topic

Al-Qraghuli, H. (2019). The defeatist behaviors of addicts in adolescence from the point of view of teachers: the causes and Counseling processors. Journal Port Science Research, 2(1), 11-41. 
[23] Baumeister, R. F., \& Scher, S. J. (1988). Self-Defeating Behavior Patterns Among Normal Individuals: Review and Analysis of Common Self-Destructive Tendencies. Psychological Bulletin, 104(1), 3-22. https://doi.org/10.1037/0033-2909.104.1.3

[24] Mervis, J. E., Lysaker, P. H., Fiszdon, J. M., Bell, M. D., Chue, A. E., Pauls, C., ... Choi, J. (2016). Addressing defeatist beliefs in work rehabilitation. Journal of Mental Health, 25(4), 366371. https://doi.org/10.3109/09638237.2016.1139069

[25] Sharif, H. M. (2015). المؤشرات السيكوباتية لاى المر اهق مدمن المخدرات >. Master Thesis, Faculty of Humanities and Social Sciences, Mohammed Khudair University, skra. http://dspace.univbiskra.dz:8080/jspui/bitstream/123456789/6939/1/45.pdf

[26] Daniel, E., \& Benish-Weisman, M. (2019). Value development during adolescence: Dimensions of change and stability. Journal of Personality, 87(3), 620-632. https://doi.org/10.1111/jopy.12420

[27] Waller, J. (2017). Composition. In Bad Arguments: 50 Common Fallacies and How to Avoid Them (pp. 250-251). wiley. https://doi.org/10.1002/9781119165811.ch53

[28] Anis, I. and Montaser, A. and Sawalhi, A. and Ahmed, M. K. (2004). المعجم الوسيط >. Arabic Language Complex, Shurooq International Library, 4(1th), https://archive.org/details/WAQmowa

[29] Campellone, T. R., Sanchez, A. H., \& Kring, A. M. (2016). Defeatist Performance Beliefs, Negative Symptoms, and Functional Outcome in Schizophrenia: A Meta-analytic Review. Schizophrenia Bulletin, 42(6), 1343-1352. https://doi.org/10.1093/schbul/sbw026

[30] Mittal, V. A., \& Walker, E. F. (2011, August 30). Diagnostic and Statistical Manual of Mental Disorders. Psychiatry Research. https://doi.org/10.1016/j.psychres.2011.06.006

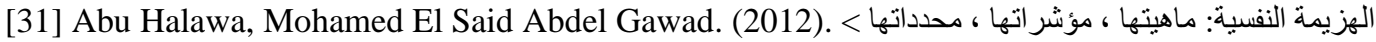
, > . Majallat al-Dirāsāt al-Tarbawīyah wa-al-Insanīyah.4 (3), تداعياتهاو الوقاية منها: دراسة في بناء المفهوم pp.177-262. https://platform.almanhal.com/details/article/67355

[32] Al Assami, Riyad. (2017). سمات الشخصية الانهزامية> >. Retrieved on April 2019 from https://www.facebook.com/1476498442377549/posts/1678474902179901/

[33] Sakhsouk, Hassan. (2014). فعالية برنامج إرشاد مصغر للتعامل مع بعض المشكلات النفسية لاى طلاب وطالبات > (Doctoral Thesis), University of Setif 2, Faculty of Humanities and Social Sciences, Algeria. https://www.univ-setif2.dz/images/PDF/doctorat/Ds1(2).pdf

[34] Reich, J. (1987). Prevalence of DSM-III-R self-defeating (masochistic) personality disorder in normal and outpatient populations. Journal of Nervous and Mental Disease, 175(1), 52-54. http://dx.doi.org/10.1097/00005053-198701000-00009

[35] Khalifa, Najm Abdul. (2012). عوامل ظاهرة الإدمان ... الأسباب والوقاية > . Azzaman International Newspape, Issue 4193, Retrieved on April 2019 from https://tinyurl.com/y66dbhx4

[36] Dearing, R. L., Stuewig, J., \& Tangney, J. P. (2005). On the importance of distinguishing shame from guilt: Relations to problematic alcohol and drug use. Addictive Behaviors, 30(7), 1392-1404. https://doi.org/10.1016/j.addbeh.2005.02.002

[37] Treatment Approaches for Drug Addiction. (2009, September 1). Retrieved November 13, 2015,from https://d14rmgtrwzf5a.cloudfront.net/sites/default/files/drugfacts_treatmentappro $\underline{\text { aches.pdf }}$

القره غولي، حسن احمد سهيل. (2019). السلوكيات الانهزامية للمدمنين في مرحلة المراهقة والشباب من وجهة نظر

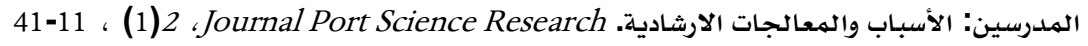


[38] Dunn, C., Deroo, L., \& Rivara, F. P. (2001). The use of brief interventions adapted from motivational interviewing across behavioral domains: A systematic review. Addiction. https://doi.org/10.1046/j.1360-0443.2001.961217253.x

[39] Kelly, T. H., Robbins, G., Martin, C. A., Fillmore, M. T., Lane, S. D., Harrington, N. G., \& Rush, C. R. (2006). Individual differences in drug abuse vulnerability: D-amphetamine and sensation-seeking status. Psychopharmacology, 189(1), 17-25. https://doi.org/10.1007/s00213$\underline{006-0487-z}$

[40] Potenza, M. N., Koran, L. M., \& Pallanti, S. (2009). The relationship between impulse-control disorders and obsessive-compulsive disorder: A current understanding and future research directions. Psychiatry Research, 170(1), 22-31. https://doi.org/10.1016/j.psychres.2008.06.036

[41] Abdul Latif, R. A. (2007). الاساليب الوقائية لمو اجهة مشكلة تعاطي المخدرات >. Symposium on the Role of Educational Institutions in Reducing Drug Abuse, Center for Studies and Research, Department of Seminars and Scientific Meetings, Naif Arab University for Security Sciences, 14-16 / 3/1428. https://repository.nauss.edu.sa/bitstream/handle/123456789/54257/EB_439.pdf?sequence=1\&isAll owed=y

[42] Barakat. B. (2009). مظاهر السلوك السلبي لاى تلاميذ المرحلة الاساسية من وجهة نظر المعلمين واساليب مواجهتهر ل > Al-Quds Open University, Tulkarem Educational Zone. https://www.ouarsenis.com/up/uploads/ouarsenis.com144725983157641.pdf

[43] Doyle, K. A. (2011). Albert Ellis and Rational Emotive Behavior Therapy: A Personal Reflection. Journal of Rational - Emotive and Cognitive - Behavior Therapy, 29(4), 207-210. https://doi.org/10.1007/s10942-011-0141-5

[44] Ellis, A. (2006). Rational emotive behavior therapy and the mindfulness-based stress reduction training of Jon Kabat-Zinn. Journal of Rational - Emotive and Cognitive - Behavior Therapy, 24(1), 63-78. https://doi.org/10.1007/s10942-006-0024-3

[45] Ellis, A. (1980). Rational-emotive therapy and cognitive behavior therapy: Similarities and differences. Cognitive Therapy and Research, 4(4), 325-340. https://doi.org/10.1007/BF01178210

[46] Al-Ghamdi, H. A. (2011) > فنيات العلاج المعرفي السلوكي>. Retrieve, date March 2019, From https://acofps.com/vb/90764.html

[47] Tosti, G. (2006). The Sociological Theories of Gabriel Tarde. Political Science Quarterly, 12(3), 490. https://doi.org/10.2307/2139668

[48] Hjelle, L. A., \& Ziegler, D. J. (1992). Personality theories : basic assumptions, research, and applications. McGraw-Hill College (pp. 440-486). Retrieved from http://psycnet.apa.org.ezprimo1.idc.ac.il/record/1992-97146-000

[49] Levant, R. F., \& Hasan, N. T. (2008). Evidence-Based Practice in Psychology. Professional Psychology: Research and Practice, 39(6), 658-662. https://doi.org/10.1037/0735-7028.39.6.658

[50] Sadeghi, F. (2014). الآثار النفسية للإدمان على المخدرات > . Journal of Psychological and Educational Studies. (2014), Tamanrasset University Center. Algeria.

[51] Kassem, M. M. (1999). الدخل الى مناهج البحث العلمي > Dar Al Nahda Arab Printing \& Publishing. https://archive.org/download/85149/937.pdf

Al-Qraghuli, H. (2019). The defeatist behaviors of addicts in adolescence from the point of view of teachers: the causes and Counseling processors. Journal Port Science Research, 2(1), 11-41. 
j. port. sci. res. Volume: 2, No: 1

استبانة السلوكيات الانهزاميـة للمـراهقين والشباب الملدمنين بصورتها النهائية عزيزي المدرس

بين يديك مجهموعة من الفقرات والبـالغة ((41)) سببـا مـن أسبـاب السلوكيـات الانهزامية، يرجى تعاونك معنا في الإجابة على كل فقرة من الاستبـانة بكل دقة وموضوعية، علماً أنه لا توجد إجابة صحيحة وأخرى خاطئة، وعليك ألا تترك أي فقرة من دون إجابة، وذلك لأغراض البحث العلهي، لا داعي لذكر الاسهم ... مع الشكر والتقدير.

طريقة الإجابة:

$$
\begin{aligned}
& \text { 1) إذا كان السبب يعد مهم جدا فضع إثارة (ل (ل) تحت البديل (دائما). }
\end{aligned}
$$

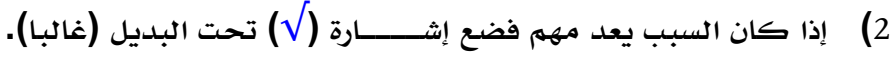

$$
\begin{aligned}
& \text { 3) إذا كان السبب يعد غير مهم فضع إثارة (ل (ل) تحت البديل (أحيانا). } \\
& \text { 4) إذا كان السبب يعد غير مهم فضع إثـارة (ل (ل) تحت البديل (أبدا). }
\end{aligned}
$$

\begin{tabular}{|c|c|c|c|c|c|}
\hline \multicolumn{4}{|c|}{ البديــــــــل } & \multirow{2}{*}{ الأسباب } & \multirow{2}{*}{$ت$} \\
\hline ابدا & أحيانا & غالبـا & دائما & & \\
\hline & & & $\sqrt{ }$ & ضعف المهارات الاجتماعية للمدمن في التعامل مع زملائه & .1 \\
\hline
\end{tabular}

\$ مثال توضيحي:

\begin{tabular}{|c|c|c|c|c|c|}
\hline ابدا & أحيانا & غالبـا & دائمــا & أسبـاب السلوكيات الانهزاميـة & الفقرة \\
\hline & & & & يرتكب المـراهق سلوكيات السرقة داخل الصف بين فترة واخرى لغرض الحصول على المال & 1 \\
\hline & & & & من السهل ان يشعر المدمن بـالهزيمـة في الحوارات والمناقشات الجماعية & 2 \\
\hline & & & & يجد المدمن صعوبة في التركيز على الدراسة او الانتبـاه لشرح المدرس & 3 \\
\hline & & & & تقلب مزاخ الهـراهق المدمن بصورة مفاجئة & 4 \\
\hline & & & & لا يتهم المدمن كثيرا الى مظهره الخارجي & 5 \\
\hline & & & & يلجأ الى التحايل والغث للحصول على درجات النجاح لضعف مستواه & 6 \\
\hline & & & & يميل المـراهق المدمن الى خداع زملائه في المدرسة والكذب عليهم & 7 \\
\hline & & & & يعاني المـراهق من السهر وقلة النوم مما يظهر عليه التعب داخل الصف & 8 \\
\hline & & & & غالبـا مـا يشعر المدمن بالوحدة والعزلة عن الاخرين & 9 \\
\hline
\end{tabular}

$$
\text { 6) اخكون الإجابة على جميع فقرات الاستبانة. }
$$


Science Research

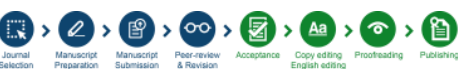
$\Rightarrow 2$

Available online www.jport.co Volume: 2, No: 1

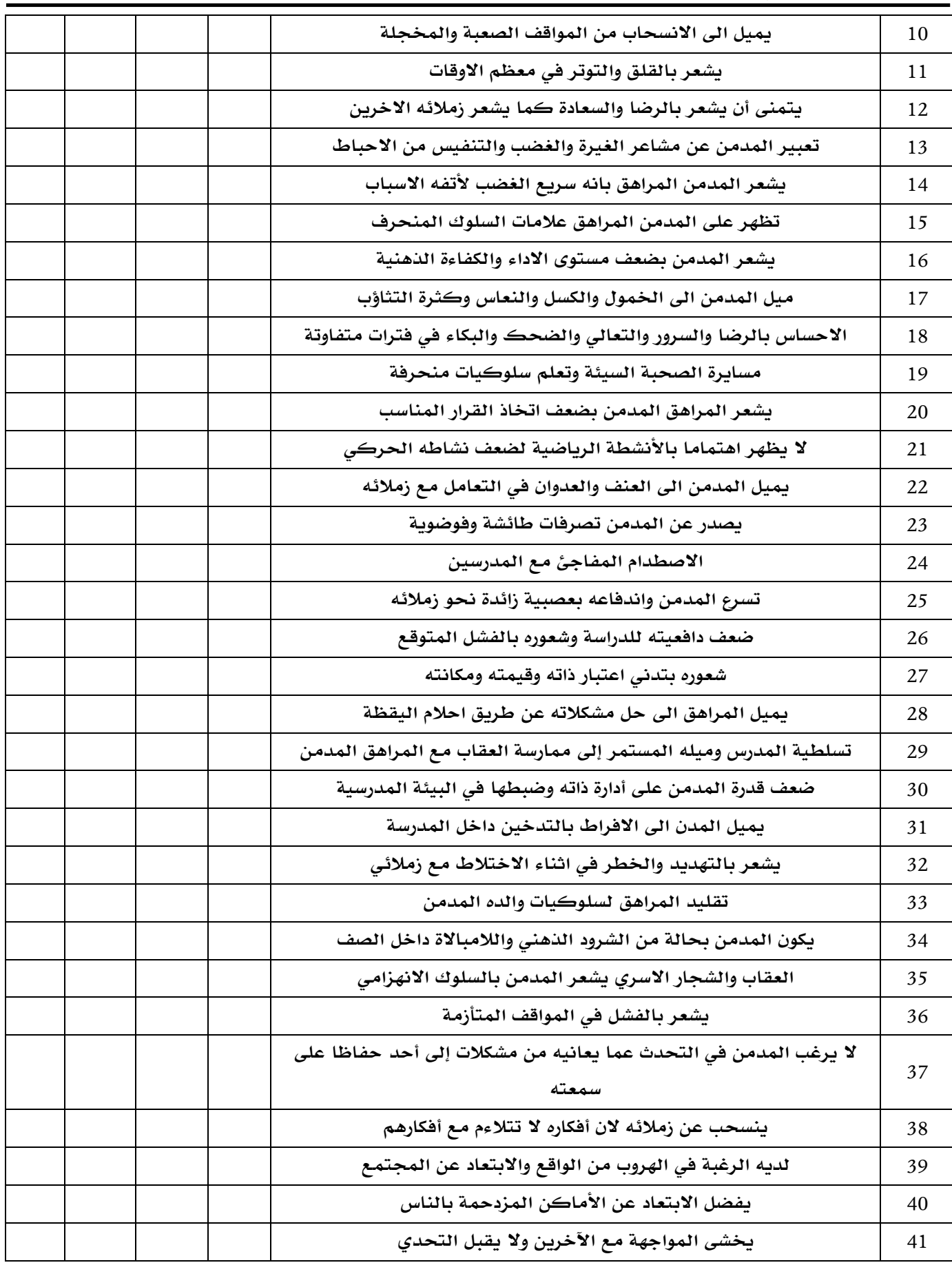

ملحق (2) 
بيـن يديـكـ مجموعـة من الفقرات والبالغة (36) معالجة من المعالجات الارشادية للسلوكيات الانهزامية لدى

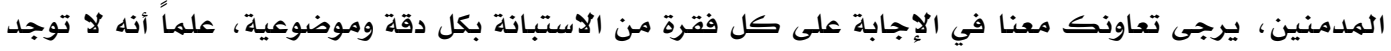
إجابة صحيحة وأخرى خاطئة، وعليك ألا تترك أي فقرة دون إجابة، وذلك لأغراض البحث العلمي، لا داعي مع الشكر والتقدير

لذكر الاسهم. .

طريقة الإجابة:

1) إذا كان الاسلوب يعد مهم جدا فضع إثارة (ل (ل) تحت البديل (مهم جدا).

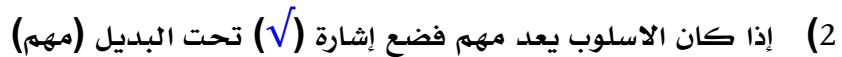

3) إذا كان الاسلوب يعد غير مهم فضع إثارة (ل)تحت البديل غير مهم).

\begin{tabular}{|c|c|c|c|c|}
\hline \multicolumn{3}{|c|}{ البديديـــــــــل } & \multirow{2}{*}{ المعالجات الارشادية للسلوكيات الانهزامية } & \multirow{2}{*}{ ت } \\
\hline غير مهم & مه & جها & & \\
\hline & $\sqrt{ }$ & & الابتعاد عن النصح المباشر بطريقة خاطئة & .1 \\
\hline
\end{tabular}

4) الكون الإجابة على جميع فقرات الاستبانة.

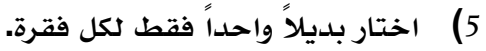

\begin{tabular}{|c|c|c|c|c|}
\hline غير & مههم & مهدا & المعالجـات الارشادية للسلوكيات الانهزامية & الفقرة \\
\hline & & & الوقاية وبناء الحصانة الذاتية والمجتمعية هي أفضل استراتيجية لمواجهة المخدرات & 1 \\
\hline & & & الاعتناء بتحسين العلاقة بين الوالدين والابناء وتوفير احتياجاتهم النفسية والعاطفية & 2 \\
\hline & & & عدم فتح المهجال امـام الابناء للبحث عن التعويض خارخ الاسـرة & 3 \\
\hline & & & التعرف الى اصدقاء الابناء وزملائهم ومعرفة كيفية قضاء الوقت معهمم & 4 \\
\hline & & & الاشراف الواعي في عدم اهمال الابناء وتركهم فريسة للصحبة السيئة والدخول في & 5 \\
\hline & & & تنهية الوعي الذاتي للمـراهقين وإبراز معلومات حقيقية ومتوازنة حول مضار المخدرات & 6 \\
\hline & & & اعداد برامـج وقائية وإصلاحية مجتمعية تسهم في بناء قدرات الشبـاب الفكرية & 7 \\
\hline & & & تدريب المراهقين على استراتيجيات الامتناع والمقاومة والمواجهة وعدم الاستسلام & 8 \\
\hline & & & استعمال فنيات الاستبصـار واظهار الدليل وتعزيز دورهم الاجتماعي & 9 \\
\hline & & & ان لا يكون الوالدان والمدرسين قدوة وانموذخ يسـاعد الهراهقين على تعله أي نوع من & 10 \\
\hline
\end{tabular}



Volume: 2, No: 1

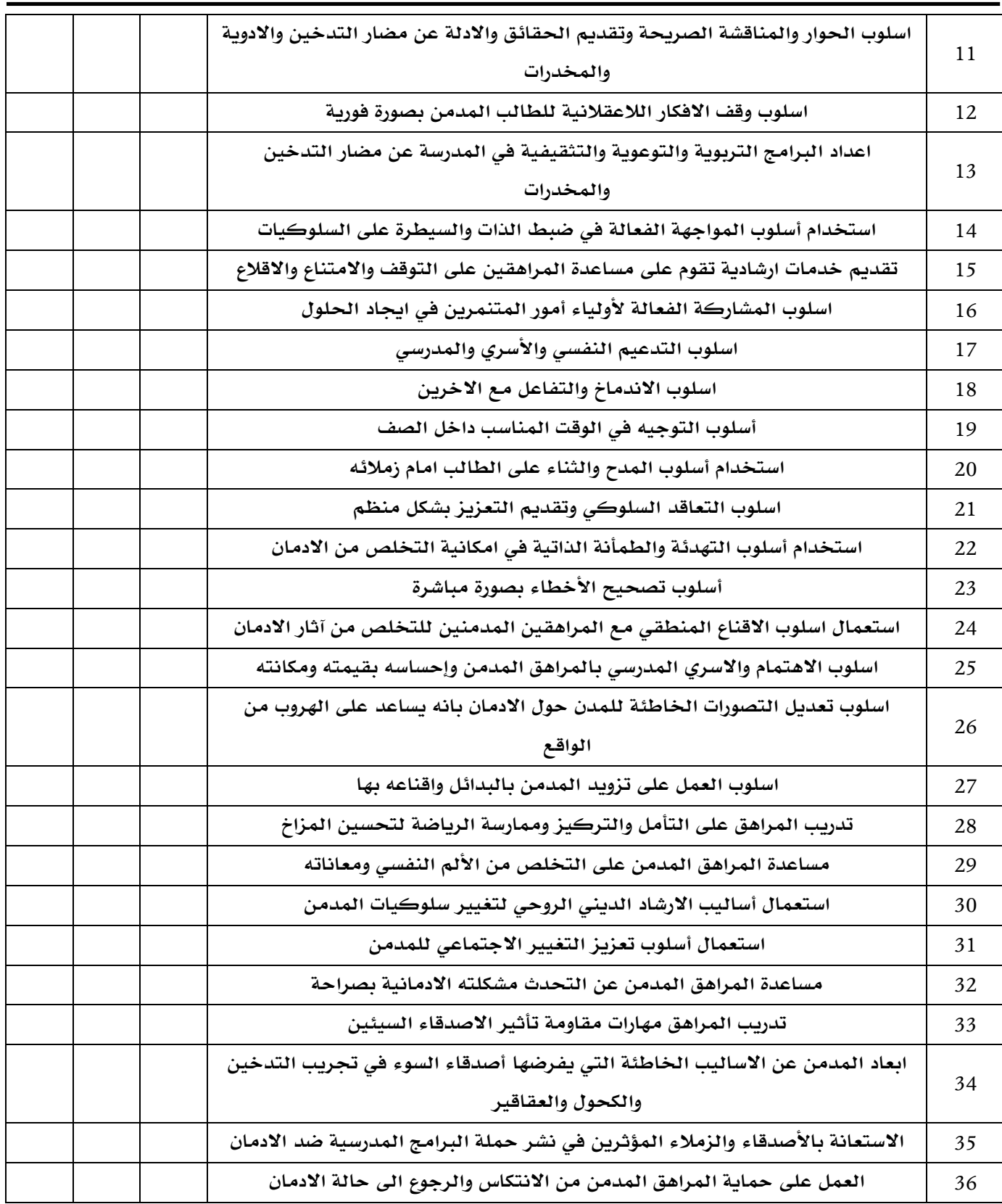

Al-Qraghuli, H. (2019). The defeatist behaviors of addicts in adolescence from the point of view of teachers: the causes and Counseling processors. Journal Port Science Research, 2(1), 11-41. 